\title{
Warming and glacier recession in the Rakaia valley, Southern Alps of New Zealand, during Heinrich Stadial 1
}

\author{
Aaron E. Putnam $^{\mathrm{a}, \mathrm{b}, *}$, Joerg M. Schaefer ${ }^{\mathrm{a}, \mathrm{c}}$, George H. Denton ${ }^{\mathrm{b}}$, David J.A. Barrell ${ }^{\mathrm{d}}$, \\ Bjørn G. Andersen ${ }^{\mathrm{e}, 1}$, Tobias N.B. Koffman ${ }^{\mathrm{b}}$, Ann V. Rowan ${ }^{\mathrm{f}}$, Robert C. Finkel ${ }^{\mathrm{g}}$, \\ Dylan H. Rood ${ }^{\text {h,i }}$, Roseanne Schwartz ${ }^{a}$, Marcus J. Vandergoes ${ }^{j}$, Mitchell A. Plummer ${ }^{k}$, \\ Simon H. Brocklehurst ${ }^{1}$, Samuel E. Kelley ${ }^{\mathrm{m}}$, Kathryn L. Ladig ${ }^{\mathrm{b}}$ \\ a Lamont-Doherty Earth Observatory of Columbia University, 61 Rt. 9W, Palisades, NY 10964, USA \\ b School of Earth and Climate Sciences and Climate Change Institute, University of Maine, Orono, ME 04469, USA \\ ${ }^{c}$ Department of Earth and Environmental Sciences, Columbia University, New York, NY 10027, USA \\ d GNS Science, Private Bag 1930, Dunedin 9054, New Zealand \\ e Department of Geosciences, University of Oslo, Oslo 0316, Norway \\ ${ }^{f}$ Centre for Glaciology, Department of Geography and Earth Sciences, Aberystwyth University, Aberystwyth, SY23 3DB Wales, UK \\ ${ }^{g}$ Department of Earth and Planetary Sciences, University of California, Berkeley, CA 95064, USA \\ h CAMS, Lawrence Livermore National Laboratory, Livermore, CA 94550, USA \\ i Scottish Universities Environmental Research Centre (SUERC), East Kilbride G75 0QF, UK \\ j GNS Science, 1 Fairway Drive, PO Box 30-368, Lower Hutt 5040, New Zealand \\ k Idaho National Laboratory, Idaho Falls, ID 83415-2107, USA \\ ${ }^{1}$ School of Earth, Atmospheric and Environmental Sciences, University of Manchester, Manchester M13 9PL, UK \\ ${ }^{\mathrm{m}}$ Department of Geology, University at Buffalo, Buffalo, NY 14260, USA
}

\section{A R T I C L E I N F O}

\section{Article history:}

Received 29 April 2013

Received in revised form 26 August 2013

Accepted 5 September 2013

Available online $\mathrm{xxxx}$

Editor: G. Henderson

\section{Keywords:}

${ }^{10} \mathrm{Be}$

surface-exposure dating

snowline

Last Glacial termination

Subtropical Front

Southern Ocean

\begin{abstract}
A B S T R A C T
The termination of the last ice age featured a major reconfiguration of Earth's climate and cryosphere, yet the underlying causes of these massive changes continue to be debated. Documenting the spatial and temporal variations of atmospheric temperature during deglaciation can help discriminate among potential drivers. Here, we present a ${ }^{10} \mathrm{Be}$ surface-exposure chronology and glaciological reconstruction of ice recession following the Last Glacial Maximum (LGM) in the Rakaia valley, Southern Alps of New Zealand. Innermost LGM moraines at Big Ben have an age of 17,840 \pm 240 yrs, whereas ice-marginal moraines or ice-molded bedrock surfaces at distances up-valley from Big Ben of $12.5 \mathrm{~km}$ (Lake Coleridge), $\sim 25 \mathrm{~km}$ (Castle Hill), $28 \mathrm{~km}$ (Double Hill), $\sim 43 \mathrm{~km}$ (Prospect Hill), and $58 \mathrm{~km}$ (Reischek knob) have ages of $17,020 \pm 70 \mathrm{yrs}, 17,100 \pm 110 \mathrm{yrs}, 16,960 \pm 370 \mathrm{yrs}, 16,250 \pm 340 \mathrm{yrs}$, and 15,660 $\pm 160 \mathrm{yrs}$, respectively. These results indicate extensive recession of the Rakaia glacier, which we attribute primarily to the effects of climatic warming. In conjunction with geomorphological maps and a glaciological reconstruction for the Rakaia valley, we use our chronology to infer timing and magnitude of past atmospheric temperature changes. Compared to an overall temperature rise of $\sim 4.65^{\circ} \mathrm{C}$ between the end of the LGM and the start of the Holocene, the glacier recession between $\sim 17,840$ and $\sim 15,660$ yrs ago is attributable to a net temperature increase of $\sim 4.0^{\circ} \mathrm{C}$ (from -6.25 to $-2.25^{\circ} \mathrm{C}$ ), accounting for $\sim 86 \%$ of the overall warming. Approximately $3.75^{\circ} \mathrm{C}(\sim 70 \%)$ of the warming occurred between $\sim 17,840$ and $\sim 16,250$ yrs ago, with a further $0.75^{\circ} \mathrm{C}(\sim 16 \%)$ increase between $\sim 16,250$ and $\sim 15,660$ yrs ago. A sustained southward shift of the Subtropical Front (STF) south of Australia between $\sim 17,800$ and $\sim 16,000$ yrs ago coincides with the warming over the Rakaia valley, and suggests a close link between Southern Ocean frontal boundary positions and southern mid-latitude climate. Most of the deglacial warming in the Southern Alps occurred during the early part of Heinrich Stadial 1 (HS1) of the North Atlantic region. Because the STF is associated with the position of the westerly wind belt, our findings support the concept that a southward shift of Earth's wind belts accompanied the early part of HS1 cooling in the North Atlantic, leading to warming and deglaciation in southern middle latitudes.
\end{abstract}

(C) 2013 Elsevier B.V. All rights reserved.

\footnotetext{
* Corresponding author.

1 Deceased.
} 


\section{Introduction}

The last glacial termination involved the largest readjustments of Earth's ocean and atmospheric circulation, ice extent, and biogeography of the past 100,000 yrs (Broecker and van Donk, 1970; Broecker and Denton, 1989; Denton et al., 2010). However, the drivers and processes contributing to the termination are not yet fully resolved and thus remain a subject of great interest (Denton et al., 2010; Clark et al., 2012; Shakun et al., 2012). Constraining the timing of ice recession from Last Glacial Maximum (LGM) limits in both polar hemispheres helps identify driving mechanisms.

Situated in the middle latitudes of the Southern Hemisphere on New Zealand's South Island, the Southern Alps are set within the austral westerly wind belt at the northern edge of the Sub-

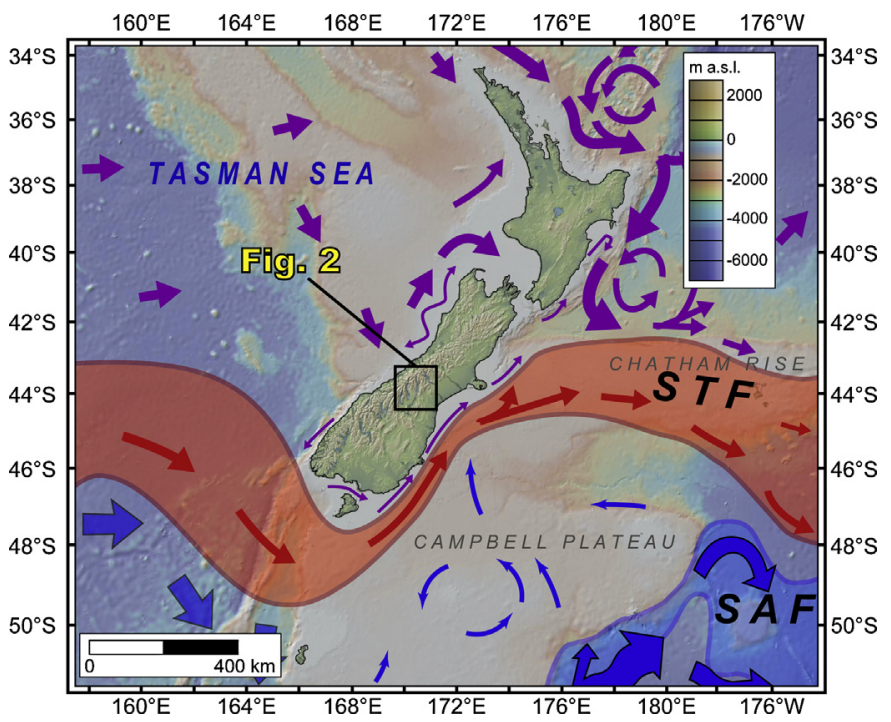

Fig. 1. Regional map of New Zealand and surrounding ocean. Purple arrows, red arrows, and blue arrows depict schematic tropical, subtropical, and Southern Ocean surface currents, respectively [physical oceanography is based on Carter et al., 1998]. Figure is adapted from Putnam et al. (2013). (For interpretation of the references to color in this figure legend, the reader is referred to the web version of this article.) tropical Front (STF) (Sikes et al., 2009; De Deckker et al., 2012) (Fig. 1). Because they lie at the southwest margin of the Pacific Ocean and thus on the opposite side of the planet from the North Atlantic Ocean, the Southern Alps are well suited for assessing interhemispheric phasing of climate events during the last glacial termination (Schaefer et al., 2006; Denton et al., 2010). Southern Alps glaciers fluctuate primarily in response to atmospheric temperature changes (Oerlemans, 1997; Anderson et al., 2006, 2010; Anderson and Mackintosh, 2006; Purdie et al., 2011; Rowan et al., 2013). The position of the STF, which is related to the position of the austral westerlies (De Deckker et al., 2012), influences Southern Alps atmospheric temperatures, and hence glacier fluctuations (Harrington, 1952; Barrows et al., 2007; Sikes et al., 2009; Putnam et al., 2010a, 2013; Bostock et al., 2013). The landforms of the Southern Alps afford a record of glacier activity during and since the LGM (Suggate, 1990; Suggate and Almond, 2005; Barrell, 2011; Barrell et al., 2011; Putnam et al., 2013) (Fig. 2). Here, we present a ${ }^{10} \mathrm{Be}$ surface-exposure chronology of moraines and ice-molded hills that document the timing of post-LGM glacier recession in the Rakaia valley, central Southern Alps. The Rakaia valley (Figs. 2 and 3 ) was occupied by a large glacier, hereafter called the Rakaia glacier, during the LGM (Barrell, 2011; Barrell et al., 2011). In unison with a regional geomorphological map encompassing the glacial landforms in the Rakaia valley (Barrell et al., 2011), the ${ }^{10}$ Be surface-exposure dating method enables a chronological reconstruction of ice recession during the last deglaciation. To derive a record of past atmospheric temperature from the glacial-geomorphologic record, we employed glaciological simulations to generate a glacier-climate reconstruction for deglaciation of the Rakaia valley. We then discuss mechanisms for the last glacial termination in southern middle latitudes.

\section{Geology and geomorphology of the Rakaia valley}

The Rakaia valley $\left(43^{\circ} \mathrm{S}, 171^{\circ} \mathrm{E}\right)$ drains a $2372-\mathrm{km}^{2}$ catchment on the southeastern side of the Southern Alps (Figs. 2 and 3). The bedrock of the Rakaia catchment is predominantly greywacke sandstone and argillite of the Triassic Rakaia Terrane (Cox and Barrell, 2007).

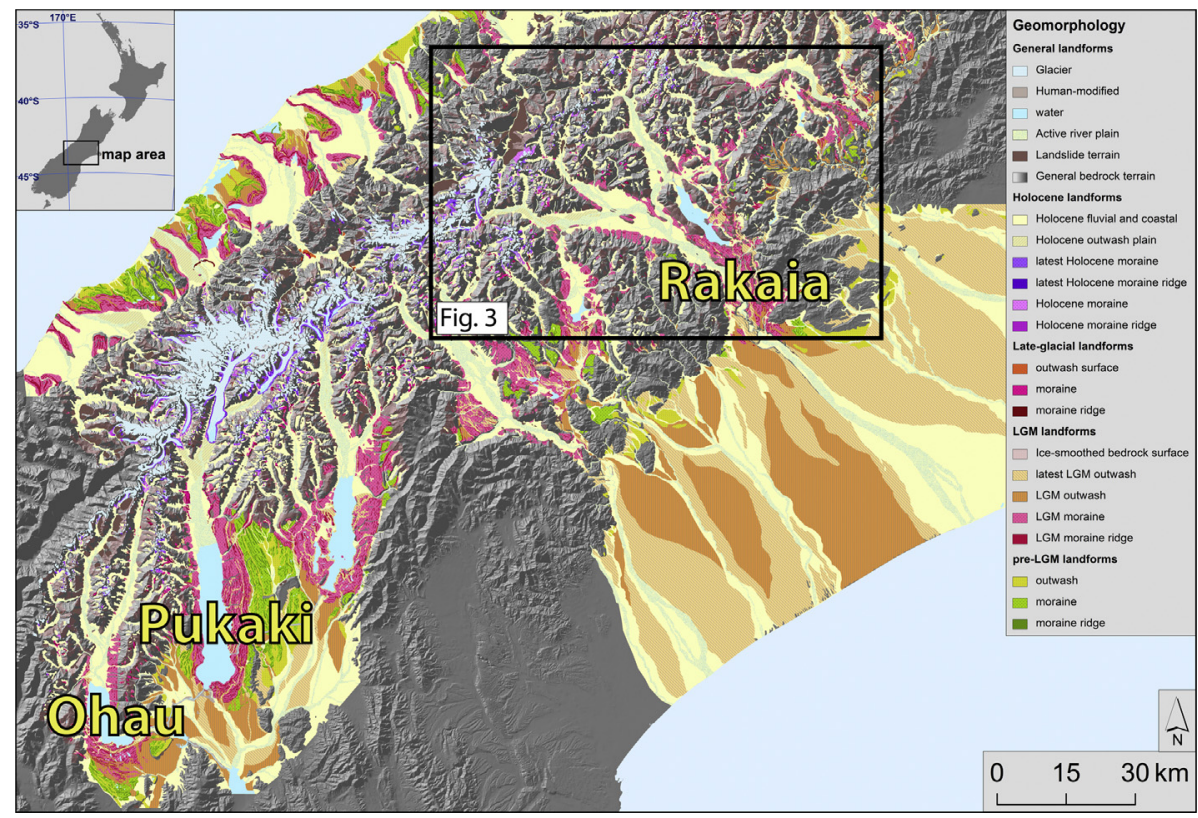

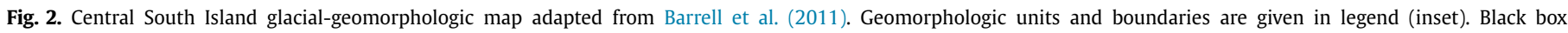

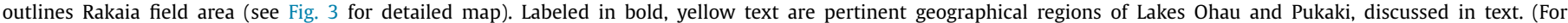
interpretation of the references to color in this figure legend, the reader is referred to the web version of this article.) 


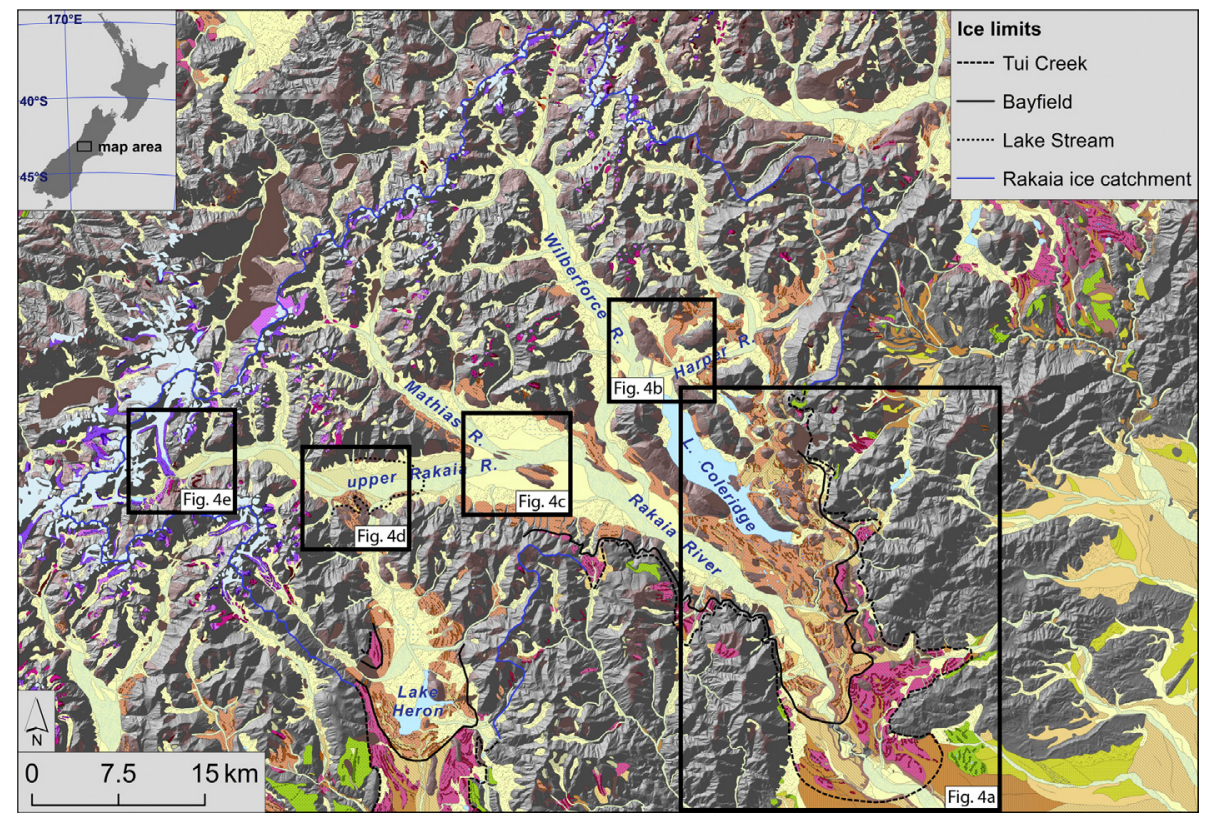

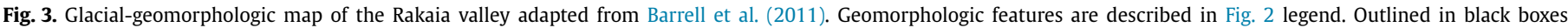
are field sites illustrated in detail in Fig. 4.

At the height of the LGM, the Rakaia glacier was produced by the coalescence of ice tongues from three major tributaries, from north to south: the Wilberforce, the Mathias, and the upper Rakaia valleys (Fig. 3). The LGM moraine/outwash sequences deposited by the Rakaia glacier have been divided into three main morphostratigraphic components. The outer component is attributed to the 'Tui Creek' advance, with successively inboard components attributed to the 'Bayfield' advance and the 'Acheron' advances (Soons, 1963). The Tui Creek, Bayfield, and Acheron components were further subdivided by number. For example, Bayfield- 1 and Bayfield-2 correspond respectively to the older and younger parts of the Bayfield moraine/outwash system (Soons, 1963; Soons and Gullentops, 1973). Prominent outwash plains extend downstream from the Tui Creek and Bayfield moraine belts but there is no recognizable outwash plain associated with the Acheron moraine belt (Suggate, 1963, 1965), although Soons and Gullentops (1973) correlated an outwash aggradation deposit exposed in Rakaia Gorge with Acheron moraines.

There is general agreement on the overall extent of the LGM moraine system of the Rakaia valley, but there is great geomorphological complexity within the moraine system arising from the extensively exposed and highly irregular bedrock floor of the Rakaia valley (Barrell, 2011; Barrell et al., 2011). As a result, the patchy and discontinuous preservation of moraines on the valley sides and floor makes the tracing of moraine belts within the LGM complex problematic. There is no better illustration of this problem than the contrasting interpretations of Soons (1963), Cox and Barrell (2007), and Shulmeister et al. (2010), wherein each shows a differing extent of the Tui Creek versus Bayfield moraine belt. Thus the differentiation between the two outer LGM moraine sets is subjective. Our interpretation of the glacial geomorphology of the Tui Creek and Bayfield moraine/outwash sets, from Barrell et al. (2011) and given in Figs. 3 and 4, is also subjective, on account of the discontinuous moraine preservation.

Fortunately, this stratigraphic problem does not prevent us from establishing a secure deglaciation chronology for the Rakaia valley. Setting aside the nomenclatural issues, our approach was to target morphologically well-defined moraines and ice-molded bedrock hills at geomorphically stable sites. We found only one suitable site within the main LGM moraine complex and this forms the start- ing point of our deglaciation chronology. This site lies east of the Acheron River and west of the Big Ben Range, and occupies the side of an un-named ice-molded bedrock hill. The hill has a generally smooth form and comprises bedrock plastered with lodgement till containing rounded clasts. The gently sloping western flank of this bedrock hill is encroached by what we refer to here as the 'Big Ben moraines', comprising an outermost sharp-crested moraine ridge, inboard (west) of which is undulating morainal topography with a series of recessional moraine ridges (Fig. 4a). These glacial deposits are thin, with solid bedrock no more than a few tens of meters below the ground surface. Although not critical to our interpretation, we think it likely that the ice-molded hill was exposed during retreat from the Tui Creek advance(s), and the Big Ben moraines were deposited at the culmination of the Bayfield advance, followed by subsequent ice withdrawal (Fig. 4).

The Big Ben moraines lie on the left-lateral flank of an extensive glacial basin formerly occupied by the Rakaia glacier, within which Soons (1963) mapped the Acheron glacial deposits. The lack of prominent outwash plains associated with the Acheron moraine system, and an abundance of discontinuous moraines and kame terraces, adjoined by glaciolacustrine landforms and deposits, led Shulmeister et al. (2010) to propose progressive withdrawal of the glacier into the Rakaia valley trough. We concur with this view, and consider that the advance culminating in the formation of the outer ridge of the Big Ben moraines, and the subsequent ice withdrawal and formation of recessional moraine ridges and kame terraces, marks the final episode of the Rakaia glacier under full LGM conditions.

About $28 \mathrm{~km}$ up the Rakaia valley from the Big Ben moraines is Double Hill, comprising two adjoining ice-molded bedrock knolls standing above the modern valley-floor floodplain near the confluence of the Mathias and upper Rakaia valleys (Figs. 3 and 4). These bedrock knolls also satisfied our sampling criterion of a geomorphically stable site, and they are plastered with glacial deposits exposed during lowering of the ice surface.

Approximately $15 \mathrm{~km}$ upstream from Double Hill, within the upper Rakaia branch of the main Rakaia valley, is Prospect Hill, an elevated, ice-molded bedrock knob veneered by glacial deposits (Figs. 3 and 4). Prospect Hill stands $\sim 230 \mathrm{~m}$ above the southern side of the upper Rakaia valley floodplain. A well-defined belt of 

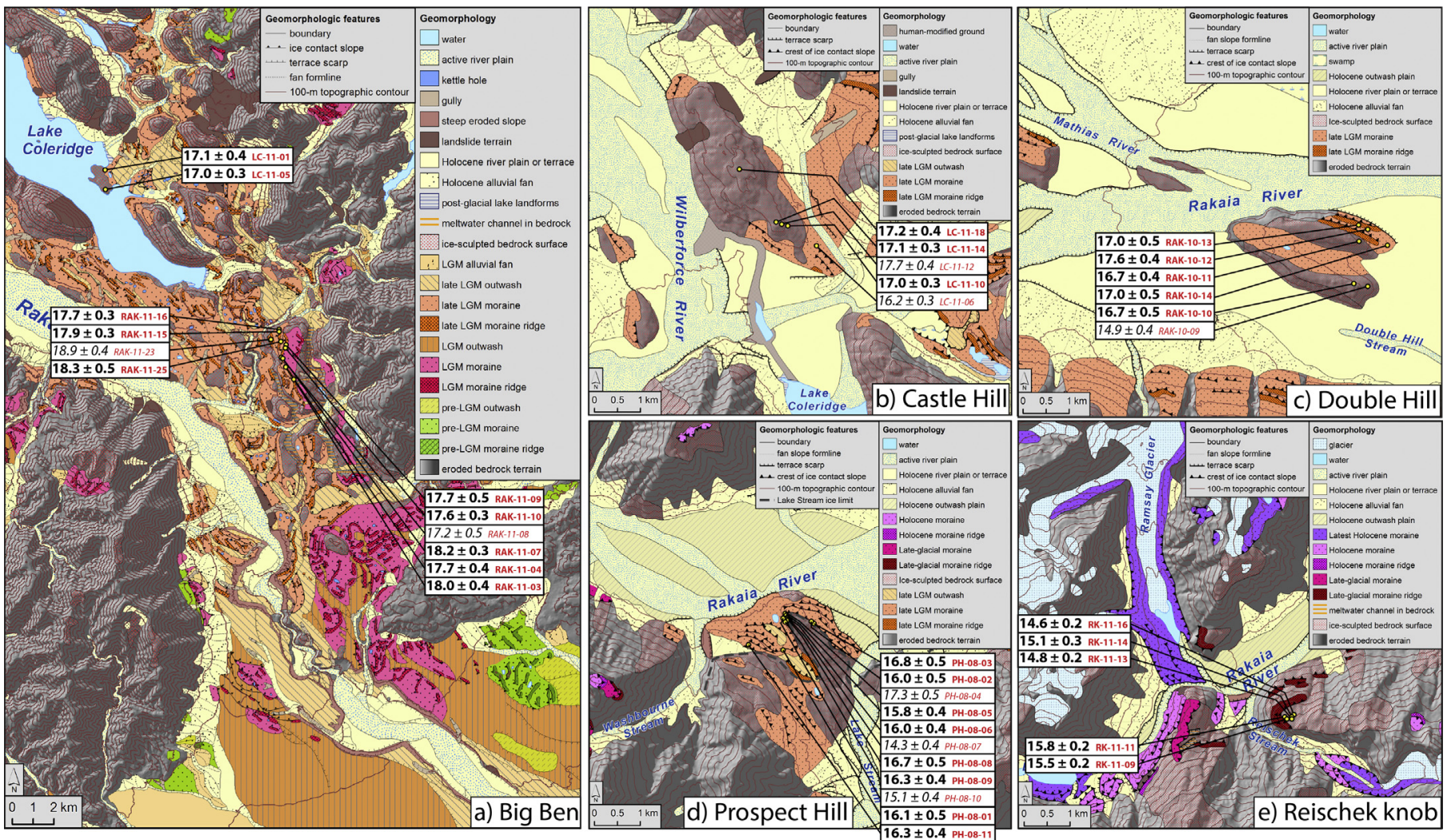

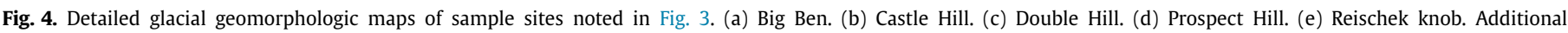

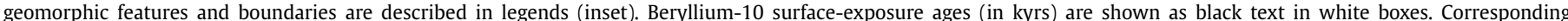

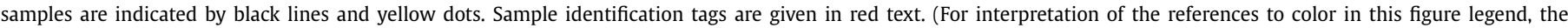
reader is referred to the web version of this article.)

moraine, with a prominent, sharp-crested 2-3 m high moraine ridge at its down-valley margin, lies on the southern, western, and northern flanks of Prospect Hill. This moraine belt delimits a latero-terminal position of the former upper Rakaia tributary glacier (hereafter upper Rakaia glacier), $\sim 43 \mathrm{~km}$ up-valley of the Big Ben moraines. Burrows and Russell (1975) attributed this moraine belt to the 'Lake Stream' advance, a late-stage pause or re-advance of the upper Rakaia glacier during the overall recession of ice within the Rakaia catchment. The Lake Stream advance (or stillstand) occurred after the distributary ice lobe of the Rakaia glacier that spilled into the Lake Heron valley withdrew into the upper Rakaia valley.

Located $\sim 15 \mathrm{~km}$ farther up-valley on the eastern side of the Reischek River tributary of the upper Rakaia valley, and standing as much as $\sim 550 \mathrm{~m}$ above the adjacent modern Rakaia floodplain, is a prominent ice-smoothed bedrock spur with a belt of parallel arcuate moraine ridges near the ice-proximal western side of the spur (Figs. 3 and 4). Burrows and Russell (1975) referred to this spur as 'High Moraine Bluff', but here we simply refer to it informally as 'Reischek knob' (Figs. 3 and 4). Much of Reischek knob is bedrock with a veneer of glacial deposits. Sloping east from the margin of the arcuate moraine belt are three narrow meltwater channels that are incised into the ice-molded bedrock terrain. The moraine belt and associated meltwater channels formed laterally to the Reischek Glacier, at a time when it was much larger and was confluent with the upper Rakaia glacier. Reischek knob is our farthest up-valley site, again satisfying our criteria of a stable geomorphic position with clear morphological context.

As an additional check, we dated landforms at two locations associated with the Wilberforce glacier, the main northern tributary of the Rakaia glacier. The main ice stream from the Wilberforce catchment merged with the Rakaia glacier at the Lake Coleridge trough (Figs. 3 and 4). We targeted an ice-molded bedrock knoll that forms a prominent peninsula on the eastern shore of Lake Coleridge, and an ice-molded bedrock knob, known as Castle Hill, in the Wilberforce valley. The peninsula at Lake Coleridge lies $\sim 12.5 \mathrm{~km}$ up-valley of the Big Ben moraines, whereas Castle Hill, lying $\sim 25 \mathrm{~km}$ up-valley of the Big Ben moraines, occupies a geomorphological position similar to that of Double Hill. The Lake Coleridge peninsula and Castle Hill became exposed as ice withdrew from the Lake Coleridge trough. The surface of Castle Hill comprises numerous ice-shorn bedrock outcrops separated by patches of ground moraine, with several discontinuous recessional moraine ridges on the lower flanks.

Key attributes of the sites we selected to document the deglaciation chronology of the Rakaia valley are that they have well-defined morphologies on flat or gently sloping land surfaces and are proximal to a solid rock foundation. These glacial landforms were exposed upon lowering of the former ice surface, and all of our sampling areas are well above the maximum ca. $440 \mathrm{~m}$ a.s.l. elevation of the ephemeral post-glacial lake that occupied the Rakaia valley axis (Shulmeister et al., 2010). Thus, these sites are essentially free of caveats in regard to slope instability, glaciokarst instability of ice-bearing ablation drift, and glaciolacustrine processes. Boulders at these sites, resting on ice-molded bedrock or rooted in glacial deposits, would have commenced their exposure to cosmic rays immediately upon ice recession, thus permitting construction of a detailed record of deglaciation in the Rakaia valley on the basis of surface-exposure dating.

\section{3. ${ }^{10} \mathrm{Be}$ surface-exposure dating methods}

Of a total of 75 boulders from which samples were collected, we selected a subset of 39 samples for ${ }^{10} \mathrm{Be}$ analysis. We chose 
samples from those boulders judged to be in particularly stable positions, and with notably well-preserved surfaces. Sampling and ${ }^{10} \mathrm{Be}$ surface-exposure dating accorded with the field and laboratory protocols described in Schaefer et al. (2009), Putnam et al. (2010a; 2010b), Kaplan et al. (2010), and available online at: http://www.ldeo.columbia.edu/tcn. Our field sampling targeted greywacke sandstone boulders embedded firmly in moraine ridges and in ground moraine, or else boulders resting in stable positions on ice-molded bedrock. We avoided sampling from boulders in proximity to patches of soil erosion, or which showed signs of having suffered spalling or exfoliation. Samples were transported to the Lamont-Doherty Earth Observatory Cosmogenic Nuclide Laboratory for processing. Isotopic measurements were undertaken at the Lawrence-Livermore National Laboratory Center for Accelerator Mass Spectrometry (LLNL CAMS).

All ${ }^{10} \mathrm{Be}$ ages were calculated using blank-corrected ${ }^{10} \mathrm{Be}$ concentrations, which we determined by subtracting the number of ${ }^{10} \mathrm{Be}$ atoms detected in procedural blanks from the number of ${ }^{10} \mathrm{Be}$ atoms measured in boulder samples. We propagated analytical uncertainties attending each sample measurement with uncertainties associated with procedural blanks. Age calculations utilized the local South Island ${ }^{10} \mathrm{Be}$ production rate for spallation [' $\mathrm{P}_{\mathrm{NZ2}}$ ' of Putnam et al., 2010b]. This production rate has been repeated by calibration efforts in southern South America (Kaplan et al., 2011), which further supports its usage in southern middle latitudes. We employed the 'Lm' scaling protocol that incorporates the altitudinal scaling of Lal (1991)/Stone (2000) and the high-resolution geomagnetic model of Lifton et al. (2008) [corresponding production rate is $3.74 \pm 0.08$ at $\mathrm{g}^{-1} \mathrm{yr}^{-1}$; see Putnam et al., 2010b for details]. Because the Rakaia valley lies only $\sim 70 \mathrm{~km}$ northeast of the Putnam et al. (2010b) production-rate calibration site in Macaulay valley, the use of different scaling methods does not produce significant variations in calculated ages, and thus the choice of scaling protocol does not alter our conclusions. Finally, in order to facilitate comparison with radiocarbon-based chronologies, we reference all ${ }^{10} \mathrm{Be}$ surface-exposure ages to the year AD1950 (i.e., yrs 'BP', and hereafter referred to as 'yrs') by subtracting 58,60, and 61 yrs from ages determined from samples collected in AD2008, AD2010, and AD2011, respectively. In discussing radiocarbon-derived ages, we state calendar ages according to IntCal09, also referred to as 'yrs'.

\section{Results}

The thirty-nine ${ }^{10} \mathrm{Be}$ surface-exposure ages obtained are internally consistent and provide a quantitative chronology of Rakaia glacier recession from LGM limits. Details of the individual samples and analytical results are set out in Appendix A, Table S1, whereas ${ }^{10} \mathrm{Be}$ surface-exposure ages are reported in Table 1 and plotted on maps in Figs. 3 and 4. Statistical representations of age populations are given in Fig. 5. Age error limits reflect analytical uncertainties only and are reported at the $1 \sigma$ level, unless otherwise stated.

\subsection{Big Ben}

Six ages determined from the sharp-crested outermost Big Ben moraine ridge range from 17,190 to 18,210 yrs old (Figs. $3-5$ ). The $17,190 \pm 460$-yr age of sample RAK-11-08 is more than two standard deviations younger than the arithmetic mean age of inboard recessional landforms (see below) and is thus considered an outlier and excluded from further discussion. The remaining five ages form an approximately normal distribution and yield an arithmetic mean age of $17,840 \pm 240$ yrs for the outermost Big Ben moraine ridge.
Four ages on boulders on recessional moraine ridges and undulating morainal topography, located just inboard of the Big Ben moraine ridge, range from 17,700 to 18,950 yrs old (Figs. $3-5$ ). The age of $18,950 \pm 360 \mathrm{yrs}$ (RAK-11-23) is an outlier, being more than $2 \sigma$ older than the mean age of the outermost Big Ben moraine ridge. Upon removal of the RAK-11-23 age, the remaining three boulder ages have an approximately normal distribution and yield an arithmetic mean of $17,960 \pm 290$ yrs for recessional moraines immediately inboard of the Big Ben outermost moraine ridge. This mean age is statistically indistinguishable from the $17,840 \pm$ 240 yrs age of the outermost moraine ridge, and attests to the withdrawal of ice from this locality no more than $\sim 300$ yrs after formation of the outermost Big Ben moraine ridge.

\subsection{Lake Coleridge and Castle Hill}

We determined exposure ages of seven boulders rooted in glacial deposits or resting on ice-molded bedrock near Lake Coleridge and at Castle Hill. Two boulders from near Lake Coleridge afforded ages of 17,070 \pm 420 and 16,970 \pm 330 yrs, giving an arithmetic mean age of $17,020 \pm 70$ yrs (Figs. 3-5). Five boulders on Castle Hill span elevations from $545 \mathrm{~m}$ (LC-11-06) to $828 \mathrm{~m}$ (LC-11-18), and thus became exposed during ice-surface lowering of $\sim 280 \mathrm{~m}$. The ages of these five boulders are $17,220 \pm$ 410 (LC-11-06 at $829 \mathrm{~m}$ elevation), $17,090 \pm 290$ (LC-11-10 at $709 \mathrm{~m}$ elevation), $17,710 \pm 390$ (LC-11-12 at $673 \mathrm{~m}$ elevation), $17,000 \pm 330$ (LC-11-14 at $614 \mathrm{~m}$ elevation), and 16,170 $\pm 310 \mathrm{yrs}$ (LC-11-18 at $554 \mathrm{~m}$ elevation). The age of 17,710 \pm 390 yrs (LC-11-12) for the boulder at $673 \mathrm{~m}$ elevation is significantly older than those of 17,220 \pm 410 (LC-11-18) and 17,090 \pm 290 yrs ago (LC-11-14) for two boulders situated higher on Castle Hill. Therefore we consider the old age of 17,710 yrs to be too old on the basis of morphostratigraphy and exclude it from further consideration. In addition, the age of $16,170 \pm 310$ yrs (LC-11-06) for the boulder at $554 \mathrm{~m}$ elevation, which is rooted in a recessional moraine at the base of Castle Hill, is more than three standard deviations younger than the $17,100 \pm 110 \mathrm{yr}$ mean age of samples LC-11-10, LC-11-14, and LC-11-18, all three of which came from higher elevations than LC-11-06. We consider two explanations for the relative youth of LC-11-06. First, it may be an outlier, and if so provides no information on the emergence history of Castle Hill. However, we have no morphostratigraphic basis on which to exclude this young age, and thus it is also possible that ice lingered at the base of Castle Hill until 16,170 \pm 310 yrs ago. Sampling and dating of additional boulders close to the LC-11-06 boulder would be necessary to evaluate these two possible explanations.

\subsection{Double Hill}

Six ages determined from boulders embedded in ground moraine mantling molded bedrock at Double Hill range from 14,890 to 17,560 yrs old (Figs. 3-5). Spanning elevations from $633 \mathrm{~m}$ (RAK-10-10) to $465 \mathrm{~m}$ (RAK-10-14), the sampled boulders became exposed during the course of $\sim 170 \mathrm{~m}$ of ice-surface lowering. One boulder (RAK-10-09; elevation $564 \mathrm{~m}$ ) returned an age of $14,890 \pm 410 \mathrm{yrs}$, and is younger than the arithmetic mean ages of Prospect Hill and Reischek knob landforms that lie well up-valley of Double Hill (see below). We therefore treat the age of sample RAK-10-09 as an outlier and exclude it from further consideration. The remaining five ages from Double Hill yield an approximately normal distribution and afford an arithmetic mean age of $16,960 \pm 370$ yrs (Fig. 5). The tightly clustered ages attest to full emergence of Double Hill from beneath ice cover over a period of no more than a few hundred years. 
Table 1

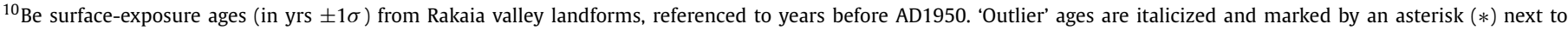
the sample ID. Bold ages ('Lm') are those discussed in text.

\begin{tabular}{|c|c|c|c|c|c|}
\hline Sample ID & $\begin{array}{l}\text { St age } \\
\text { (yrs) }\end{array}$ & $\begin{array}{l}\text { De age } \\
\text { (yrs) }\end{array}$ & $\begin{array}{l}\text { Du age } \\
\text { (yrs) }\end{array}$ & $\begin{array}{l}\text { Li age } \\
\text { (yrs) }\end{array}$ & $\begin{array}{l}\text { Lm age } \\
\text { (yrs) }\end{array}$ \\
\hline \multicolumn{6}{|c|}{ Big Ben outermost moraine ridge } \\
\hline RAK-11-03 & $18,060 \pm 390$ & $18,160 \pm 390$ & $18,100 \pm 390$ & $18,240 \pm 390$ & $17,960 \pm 390$ \\
\hline RAK-11-04 & $17,760 \pm 330$ & $17,860 \pm 330$ & $17,800 \pm 330$ & $17,940 \pm 340$ & $17,670 \pm 330$ \\
\hline RAK-11-07 & $18,320 \pm 340$ & $18,420 \pm 340$ & $18,370 \pm 340$ & $18,510 \pm 350$ & $18,210 \pm 340$ \\
\hline$R A K-11-08$ & $17,270 \pm 460$ & $17,390 \pm 470$ & $17,330 \pm 460$ & $17,470 \pm 470$ & $17,190 \pm 460$ \\
\hline RAK-11-09 & $17,840 \pm 500$ & $17,940 \pm 500$ & $17,870 \pm 500$ & $18,010 \pm 510$ & $17,740 \pm 500$ \\
\hline RAK-11-10 & $17,740 \pm 330$ & $17,830 \pm 340$ & $17,770 \pm 330$ & $17,910 \pm 340$ & $17,640 \pm 330$ \\
\hline \multicolumn{6}{|c|}{ Big Ben recessional moraine ridges } \\
\hline RAK-11-15 & $18,000 \pm 340$ & $18,150 \pm 340$ & $18,110 \pm 340$ & $18,250 \pm 340$ & $17,920 \pm 340$ \\
\hline RAK-11-16 & $17,780 \pm 340$ & $17,940 \pm 340$ & $17,890 \pm 340$ & $18,030 \pm 340$ & $17,700 \pm 330$ \\
\hline$R A K-11-23$ & $19,000 \pm 360$ & $19,140 \pm 360$ & $19,100 \pm 360$ & $19,240 \pm 360$ & $18,890 \pm 360$ \\
\hline RAK-11-25 & $18,360 \pm 450$ & $18,510 \pm 460$ & $18,460 \pm 460$ & $18,600 \pm 460$ & $18,270 \pm 450$ \\
\hline \multicolumn{6}{|c|}{ Lake Coleridge peninsula } \\
\hline LC-11-01 & $17,110 \pm 430$ & $17,350 \pm 430$ & $17,320 \pm 430$ & $17,470 \pm 430$ & $17,070 \pm 420$ \\
\hline LC-11-05 & $17,010 \pm 330$ & $17,240 \pm 330$ & $17,200 \pm 330$ & $17,350 \pm 330$ & $16,970 \pm 330$ \\
\hline \multicolumn{6}{|l|}{ Castle Hill } \\
\hline LC-11-06 & $16,200 \pm 310$ & $16,430 \pm 320$ & $16,380 \pm 320$ & $16,540 \pm 320$ & $16,170 \pm 310$ \\
\hline LC-11-10 & $17,060 \pm 330$ & $17,250 \pm 330$ & $17,190 \pm 330$ & $17,350 \pm 330$ & $17,000 \pm 330$ \\
\hline$L C-11-12$ & $17,790 \pm 400$ & $17,940 \pm 400$ & $17,870 \pm 400$ & $18,030 \pm 400$ & $17,710 \pm 390$ \\
\hline LC-11-14 & $17,160 \pm 290$ & $17,290 \pm 300$ & $17,220 \pm 300$ & $17,380 \pm 300$ & $17,090 \pm 290$ \\
\hline LC-11-18 & $17,330 \pm 410$ & $17,370 \pm 410$ & $17,280 \pm 410$ & $17,440 \pm 420$ & $17,220 \pm 410$ \\
\hline \multicolumn{6}{|l|}{ Double Hill } \\
\hline$R A K-10-09$ & $14,890 \pm 410$ & $15,120 \pm 420$ & $15,080 \pm 420$ & $15,230 \pm 420$ & $14,890 \pm 410$ \\
\hline RAK-10-10 & $16,700 \pm 460$ & $16,880 \pm 470$ & $16,830 \pm 460$ & $16,980 \pm 470$ & $16,650 \pm 460$ \\
\hline RAK-10-11 & $16,680 \pm 450$ & $16,930 \pm 460$ & $16,900 \pm 460$ & $17,050 \pm 460$ & $16,650 \pm 450$ \\
\hline RAK-10-12 & $17,600 \pm 430$ & $17,860 \pm 430$ & $17,830 \pm 430$ & $17,980 \pm 440$ & $17,560 \pm 430$ \\
\hline RAK-10-13 & $17,000 \pm 510$ & $17,250 \pm 520$ & $17,220 \pm 520$ & $17,380 \pm 520$ & $16,970 \pm 510$ \\
\hline RAK-10-14 & $16,990 \pm 450$ & $17,260 \pm 460$ & $17,230 \pm 460$ & $17,380 \pm 460$ & $16,970 \pm 450$ \\
\hline \multicolumn{6}{|c|}{ Prospect Hill } \\
\hline PH-08-01 & $16,200 \pm 510$ & $16,310 \pm 516$ & $16,250 \pm 510$ & $16,388 \pm 520$ & $16,140 \pm 510$ \\
\hline PH-08-02 & $16,100 \pm 470$ & $16,220 \pm 470$ & $16,160 \pm 470$ & $16,299 \pm 470$ & $16,040 \pm 470$ \\
\hline $\mathrm{PH}-08-03$ & $16,900 \pm 510$ & $17,010 \pm 510$ & $16,950 \pm 510$ & $17,090 \pm 520$ & $16,820 \pm 510$ \\
\hline PH-08-04 & $17,500 \pm 450$ & $17,470 \pm 450$ & $17,390 \pm 450$ & $17,530 \pm 450$ & $17,350 \pm 450$ \\
\hline PH-08-05 & $15,900 \pm 420$ & $15,900 \pm 420$ & $15,820 \pm 420$ & $15,960 \pm 430$ & $15,790 \pm 420$ \\
\hline PH-08-06 & $16,100 \pm 360$ & $16,130 \pm 360$ & $16,050 \pm 360$ & $16,180 \pm 370$ & $16,020 \pm 360$ \\
\hline PH-08-07 & $14,320 \pm 410$ & $14,400 \pm 410$ & $14,320 \pm 410$ & $14,460 \pm 420$ & $14,290 \pm 410$ \\
\hline PH-08-08 & $16,750 \pm 480$ & $16,770 \pm 480$ & $16,680 \pm 480$ & $16,820 \pm 480$ & $16,650 \pm 480$ \\
\hline PH-08-09 & $16,360 \pm 440$ & $16,380 \pm 440$ & $16,300 \pm 440$ & $16,440 \pm 450$ & $16,270 \pm 440$ \\
\hline $\mathrm{PH}-08-10$ & $15,190 \pm 450$ & $15,240 \pm 450$ & $15,170 \pm 450$ & $15,300 \pm 450$ & $15,130 \pm 450$ \\
\hline PH-08-11 & $16,340 \pm 380$ & $16,410 \pm 380$ & $16,340 \pm 380$ & $16,480 \pm 390$ & $16,260 \pm 380$ \\
\hline \multicolumn{6}{|c|}{ Reischek knob I: till-veneered bedrock } \\
\hline RK-11-09 & $15,700 \pm 170$ & $15,340 \pm 160$ & $15,200 \pm 160$ & $15,320 \pm 160$ & $15,550 \pm 160$ \\
\hline RK-11-11 & $15,930 \pm 160$ & $15,560 \pm 160$ & $15,420 \pm 160$ & $15,540 \pm 160$ & $15,770 \pm 160$ \\
\hline \multicolumn{6}{|c|}{ Reischek knob II: meltwater channel } \\
\hline RK-11-13 & $14,890 \pm 170$ & $14,570 \pm 160$ & $14,440 \pm 160$ & $14,560 \pm 160$ & $14,770 \pm 170$ \\
\hline RK-11-14 & $15,270 \pm 330$ & $14,940 \pm 320$ & $14,800 \pm 320$ & $14,920 \pm 320$ & $15,130 \pm 330$ \\
\hline RK-11-16 & $14,750 \pm 170$ & $14,450 \pm 170$ & $14,320 \pm 160$ & $14,430 \pm 170$ & $14,640 \pm 170$ \\
\hline
\end{tabular}

\subsection{Prospect Hill}

Eleven ages on boulders protruding from the Lake Stream moraine belt range from 14,290 to 17,350 yrs old (Figs. 3-5). The $17,350 \pm 450 \mathrm{yr}$ age of sample PH-08-04 is older than the arithmetic mean age of Double Hill landforms, and thus is considered an outlier. In addition, ages of samples PH-08-07 (14,290 \pm 410 yrs $)$ and PH-08-10 (15,130 \pm 450 yrs) are younger than the ages of the Reischek knob landforms (see below), and are therefore also classed as outliers. The remaining eight ages form an approximately normal distribution and yield an arithmetic mean age of $16,250 \pm 340$ yrs (Fig. 5).

\subsection{Reischek knob}

Samples RK-11-09 and RK-11-11 are from boulders rooted in ground moraine overlying bedrock outboard of a prominent set of moraine ridges (Figs. $3-5$ ). These samples gave ages of $15,550 \pm$ 160 and $15,770 \pm 160$ yrs, producing an arithmetic mean age of $15,660 \pm 160$ yrs (Fig. 5).

Samples RK-11-13, RK-11-14, and RK-11-16 are from boulders in a meltwater channel that descends from the outermost part of the moraine belt on the western side of Reischek knob. This meltwater channel and the moraine from which it emanates are the youngest morphostratigraphic features considered here. Ages of these three samples range from 14,640 to 15,130 yrs, and afford an arithmetic mean age of $14,850 \pm 250$ yrs (Fig. 5).

\section{Chronology of recession of the Rakaia glacier}

Our ${ }^{10} \mathrm{Be}$ surface-exposure ages of glacial landforms show that $17,840 \pm 240$ yrs ago, the Rakaia glacier margin was at the outermost Big Ben moraine. Ice recession was underway within no more than a few centuries, judging from the mean age of 

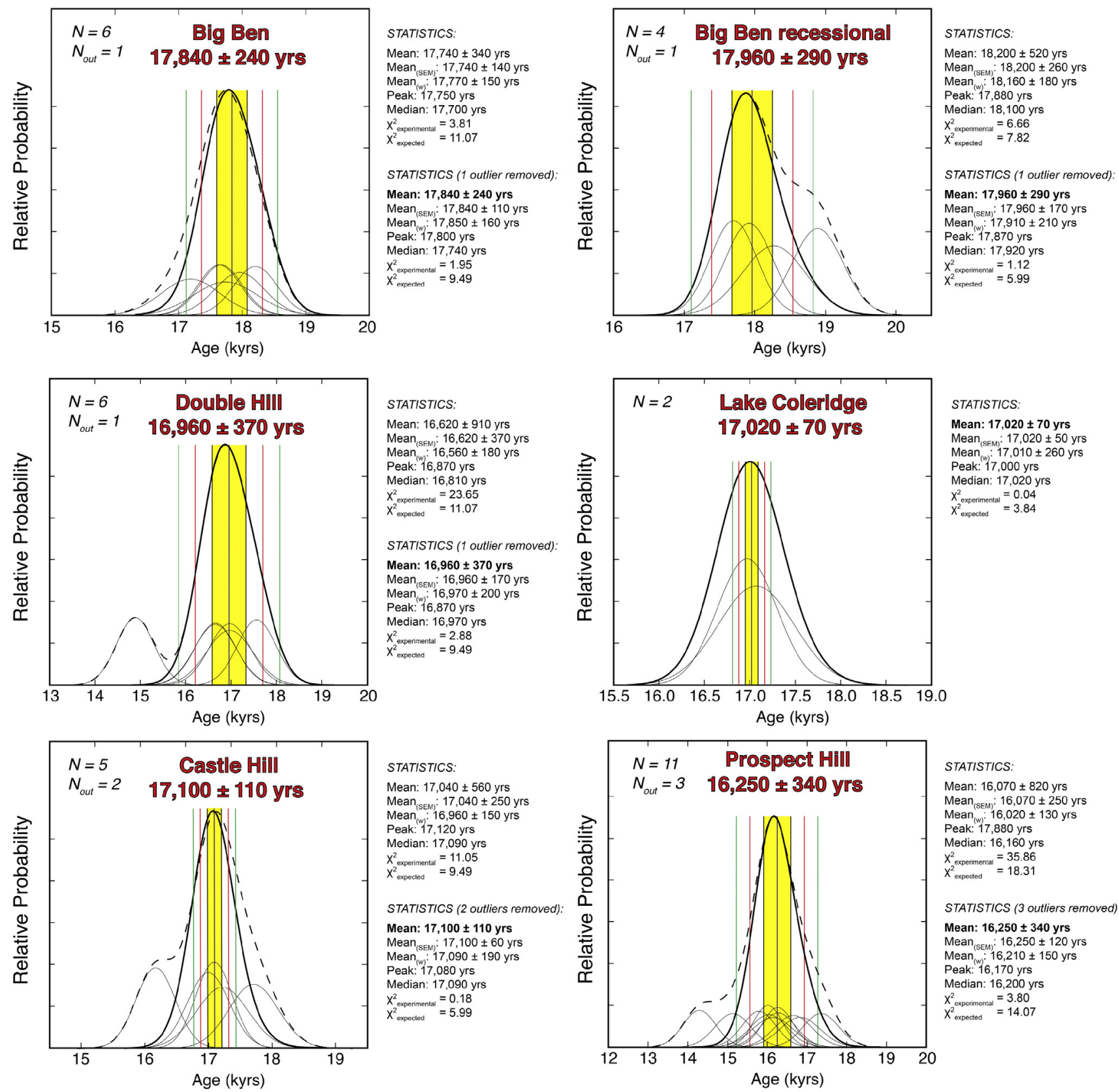

STATISTICS:

Mean: $17,040 \pm 560 \mathrm{yrs}$ Mean $_{\text {(SEM) }}: 17,040 \pm 250$ yrs Mean $16,960 \pm 150$ yrs Peak: 17,120 yrs Median: 17,090 yrs $x^{2}=11.05$

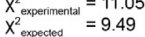

STATISTICS (2 outliers removed): Mean: $17,100 \pm 110$ yrs Mean $_{\text {(SEM) }}: 17,100 \pm 60 \mathrm{yrs}$ Mean $_{(\mathrm{wEN})}: 17,090 \pm 190 \mathrm{yrs}$ Peak: 17,080 yrs Median: $17,090 \mathrm{yrs}$ $X_{\text {experinental }}^{2}=0.18$

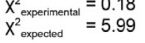
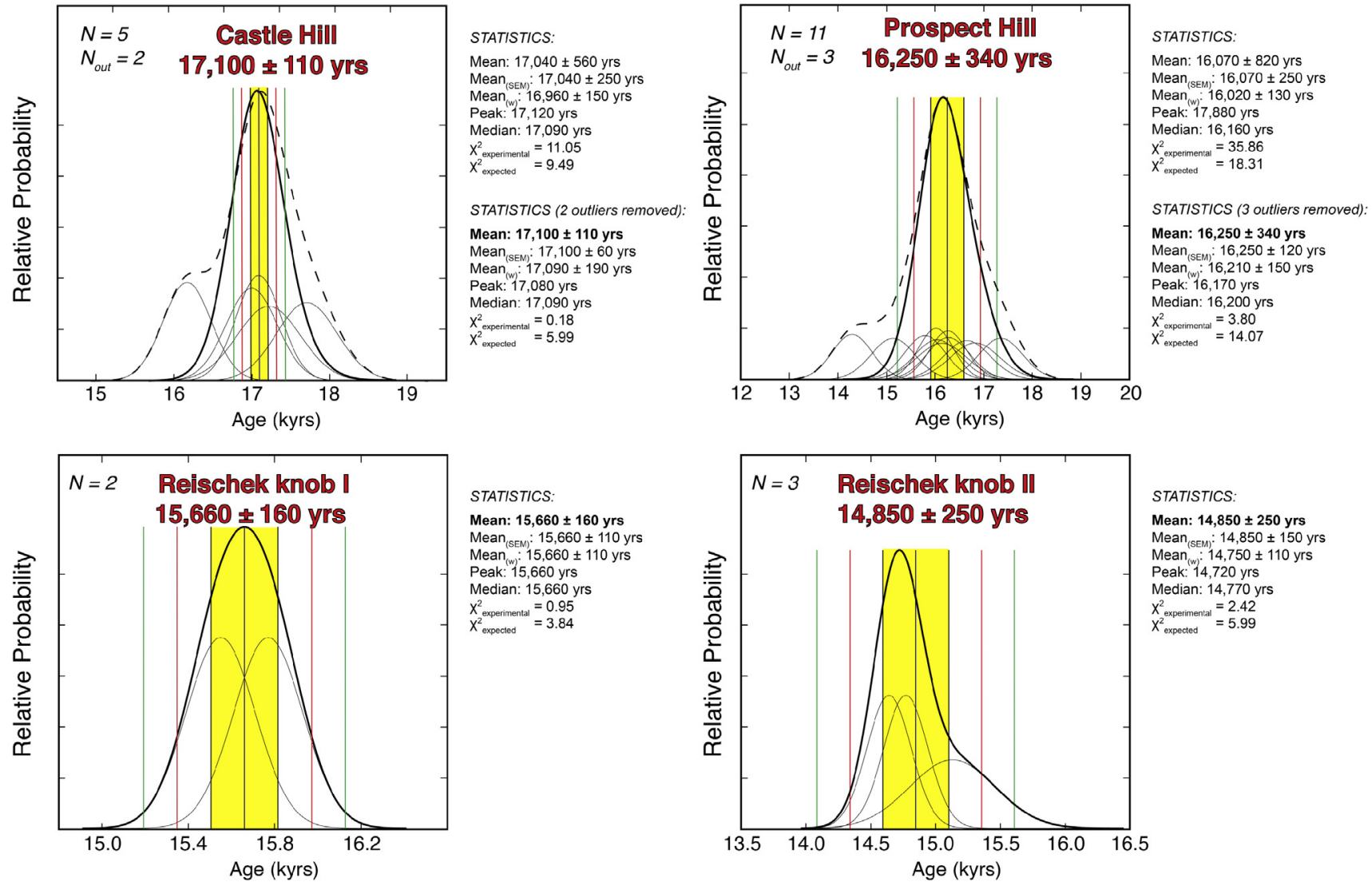

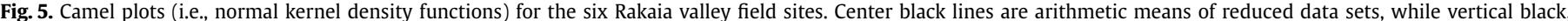

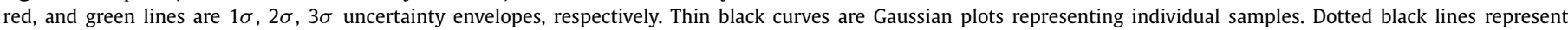

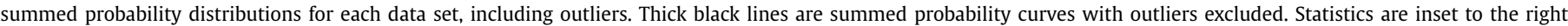

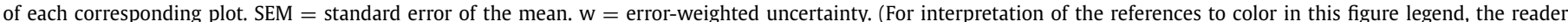
is referred to the web version of this article.) 
$17,960 \pm 290$ yrs for the recessional moraine complex at Big Ben. By $16,960 \pm 370$ yrs ago, Double Hill had become ice free, implying recession to a position $\sim 28 \mathrm{~km}$ up-valley from the Big Ben moraines. As Double Hill lies at the Rakaia/Mathias valley confluence, these two major ice tributaries probably separated at about that time.

Likewise, by 17,020 \pm 70 yrs ago ice-molded bedrock east of Lake Coleridge (12.5 km up-valley of the Big Ben moraines) had become ice free, and by $17,100 \pm 110$ yrs ago Castle Hill $(25 \mathrm{~km}$ up-valley of the Big Ben moraines) had mostly, if not entirely, emerged from beneath the ice. As noted above, one date allows for the possibility that ice lingered at the base of Castle Hill until $\sim 16,170$ yrs ago. Altogether, our chronology indicates that a reduction of $50 \%$ of the length of the glacier draining the Wilberforce tributary valley occurred in no more than $\sim 2000$ yrs, but probably closer to $\sim 1000$ yrs, following recession from the Big Ben moraines, coeval with ice retreat in the Rakaia valley.

Recession of ice within the upper Rakaia tributary was punctuated by a stillstand or re-advance of the upper Rakaia glacier terminus at 16,250 \pm 350 yrs ago, forming the Lake Stream moraines at Prospect Hill, $\sim 43 \mathrm{~km}$ up-valley of the Big Ben moraines. Because these moraines lie at the upstream end of an ice distributary valley extending from the upper Rakaia valley into the Lake Heron basin, the implication is that ice had vacated that distributary by the time that the Lake Stream moraines were formed. By $15,660 \pm 160$ yrs ago, the surface of the upper Rakaia glacier, and its Reischek Glacier tributary, had lowered sufficiently to expose Reischek knob, $\sim 58 \mathrm{~km}$ up-valley of the Big Ben moraines. Stabilization of the ice tongue at the Reischek knob moraine belt initially furnished a source of meltwater that cut an outwash channel into the molded bedrock surface. Further recession by $14,850 \pm 250$ yrs ago stemmed the meltwater flow and caused the channel to become abandoned.

\section{Glacier-inferred palaeoclimate reconstruction}

Integration of the Rakaia glacier landform chronology obtained in this study with glaciological simulations permits the estimation of atmospheric temperature changes between $\sim 17,800$ and $\sim 14,800$ yrs ago. To calculate glacier extent associated with different climatic parameters, we applied the Plummer and Phillips (2003) 2-D energy-mass balance and ice-flow model. We limited the values used for temperature input to the model to increments of $0.25^{\circ} \mathrm{C}$ so as not to imply a greater level of precision than is possible using a numerical model (Rowan et al., 2013). Validation of the model is afforded by a generally good agreement between modeled glacier extents, mapped terminal and lateral moraine positions in the Rakaia catchment, and dating results, notably that Double Hill and Castle Hill have approximately the same exposure ages, and the model implies that ice receded from both locations at about the same time. In alignment with previous empirical and modeling studies of glaciers in the Southern Alps (Oerlemans, 1997; Anderson, 2005; Anderson et al., 2006, 2010; Anderson and Mackintosh, 2006, 2012; Purdie et al., 2011; Doughty et al., 2012; Golledge et al., 2012; Kaplan et al., 2013; Putnam et al., 2013), we consider temperature to be the primary driver of LGM glacier advance/retreat, and therefore examined only temperature effects in our glacier modeling estimates of climatic conditions. However, Rakaia glacier sensitivity to other climate parameters, notably precipitation amount and distribution, is evaluated by Rowan et al. (2013; data repository). We conducted a series of glaciological simulations using a range of different atmospheric temperatures relative to modern values (hereafter referred to as $\Delta T$ ) to identify the $\Delta T$ value necessary to sustain the Rakaia glacier at its late LGM position near the Big Ben moraines, and at recessional positions corresponding to our sample sites at Cas- tle Hill, Double Hill, Prospect Hill, and Reischek knob (see Fig. 6). In these simulations, a hypothetical steady state where integrated glacier mass balance is equal to zero was reached within 400 yrs of a given temperature change. Taken together, our chronology and modeling results indicate atmospheric $\Delta T$ values of $-6.25,-4.75$, $-4.5,-3.0,-2.25$, and $-2.25^{\circ} \mathrm{C}$ at $17,840 \pm 240,17,100 \pm 110$, $16,960 \pm 370,16,250 \pm 340,15,660 \pm 160$, and $14,850 \pm 250 \mathrm{yrs}$ ago, respectively (Fig. 6).

Our results indicate a full-glacial $\Delta T$ of $-6.25^{\circ} \mathrm{C}$, when the Rakaia glacier constructed the Big Ben moraines $\sim 17,840$ yrs ago. The Rowan et al. (2013) reconstruction indicates that a $\Delta T$ of $-6.5^{\circ} \mathrm{C}$ is necessary in order to sustain the Rakaia glacier at its most outboard LGM position within the Tui Creek moraine belt, about $10 \mathrm{~km}$ down-valley from the Big Ben/Bayfield moraine belt. We cannot resolve whether the withdrawal of the Rakaia glacier from the Tui Creek limit to the Bayfield position simply reflects uncertainties associated with the application of the glacier model and representation of the LGM climatology (Rowan et al., 2013), minor climatic amelioration (as is inferred in the quantitative glaciological modeling reconstruction), or is the result of geomorphological processes, such as changes in ice extent due to glacier bed profile evolution (e.g., McKinnon et al., 2012).

Recession of the Rakaia glacier, which we infer to have been driven by atmospheric warming, commenced shortly after $17,840 \pm 240$ yrs ago. Modeled $\Delta T$ values for the Rakaia glacier indicate that a warming of $\sim 4.0^{\circ} \mathrm{C}$ took place between $\sim 17,840$ and $\sim 15,660$ yrs ago (Fig. 7). Net temperature rise of $\sim 3.25^{\circ} \mathrm{C}$ during the first $\sim 1600$ yrs of this interval represents an average annual warming rate of $\sim 2.0^{\circ} \mathrm{C}$ per thousand years. We infer a temporary stabilization of temperature slightly before $\sim 16,250$ yrs ago, that led to the pause in ice retreat, or re-advance, that formed the Lake Stream moraines. The succeeding interval of retreat implies a $0.75^{\circ} \mathrm{C}$ temperature rise over $\sim 600$ yrs, equating to an average warming rate of $1.25^{\circ} \mathrm{C}$ per thousand years. Another stabilization of the Rakaia ice margin occurred between $\sim 15,660$ and $\sim 14,850$ yrs ago at the Reischek knob moraines that represent the youngest glacier position examined in our study (Fig. 6).

A $\Delta T$ of $-6.25^{\circ} \mathrm{C}$ at $\sim 17,840$ yrs ago inferred for the Rakaia valley is indistinguishable from $\Delta T$ values of $-6.25 \pm 0.5^{\circ} \mathrm{C}$ and $-6.25 \pm 0.25^{\circ} \mathrm{C}$ for the LGM determined by glacier modeling of the Lake Ohau catchment of the central Southern Alps (Putnam et al., 2013) and the entire Southern Alps icefield (Golledge et al., 2012), respectively. Our results from the Rakaia valley are also consistent with $\sim 3.6^{\circ} \mathrm{C}$ of warming registered between $\sim 17,700$ and $\sim 13,000$ yrs ago in the Lake Ohau catchment (Kaplan et al., 2010; Doughty et al., 2012; Putnam et al., 2013). Moreover, on the basis of palaeosnowline reconstructions, Putnam et al. (2012) and Kaplan et al. $(2010,2013)$ demonstrated an overall temperature rise of $\sim 0.65^{\circ} \mathrm{C}$ during the late-glacial interval between ca. 15,000 and 11,500 yrs ago, and also that atmospheric temperatures were $\sim 1.6^{\circ} \mathrm{C}$ cooler than modern values in the Southern Alps in the earliest Holocene, after which air temperatures gradually increased toward pre-industrial values by the middle Holocene. Combining our results with those from late-glacial and Holocene palaeosnowline reconstructions, we obtain a net warming of $\sim 4.65^{\circ} \mathrm{C}$ between $\sim 17,800$ and $\sim 11,500$ yrs ago in the Southern Alps, with an additional $\sim 1.6^{\circ} \mathrm{C}$ warming during the first half of the Holocene (Kaplan et al., 2010, 2013; Putnam et al., 2012). Of the overall $\sim 4.65^{\circ} \mathrm{C}$ temperature rise that had occurred by the beginning of the Holocene, 38\% took place between 17,840 and 16,960 yrs ago, a further $32 \%$ had been accomplished by $\sim 16,250$ yrs ago, and an additional 16\% (totaling 86\%) was achieved between 16,250 and 15,660 yrs ago (Figs. 6 and 7).

The modeling assumes that the glacier was in equilibrium with climate when it receded from each of the dated positions. Conceivably, temperatures were higher and the glacier was receding 

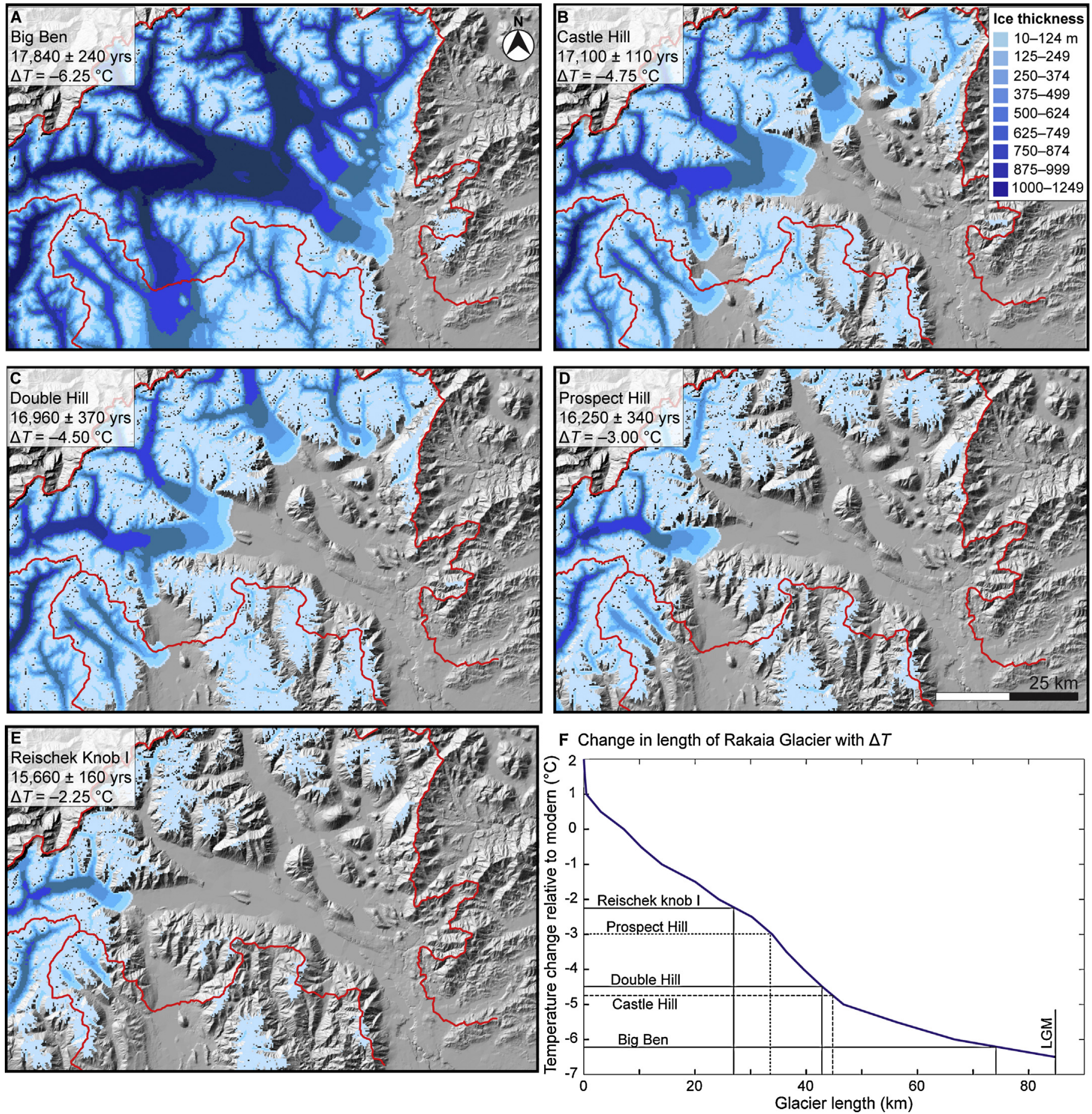

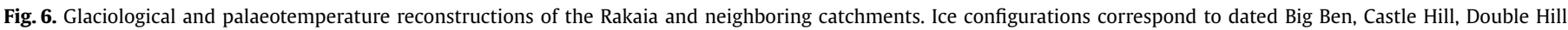

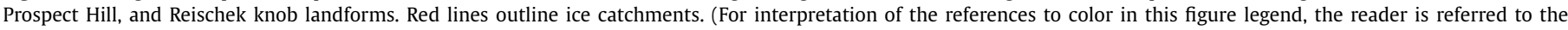
web version of this article.)

in disequilibrium. In that case, our temperature estimates and inferred rates of warming would be minimum values.

\section{Discussion}

High-quality chronological information is a requirement for developing solid mechanistic interpretations of past climate change. Thus, we aimed to develop a chronology of glacier-inferred atmospheric temperature change in the Southern Alps sufficiently resolved to compare with other well-dated palaeoclimatic and palaeoceanographic records.
First, we compare our results to previous ${ }^{10} \mathrm{Be}$ surface-exposure ages from the Rakaia valley reported by Shulmeister et al. (2010). Looking specifically at what they refer to as the Bayfield, Acheron and Coleridge sectors of the moraine sequence, we think it likely that their Bayfield terminal moraine correlates with our Big Ben outermost moraine ridge, and their inner Bayfield and Acheron moraines correlate, at least in part, with our Big Ben recessional moraines. Their 'Coleridge' samples come from a geomorphic position intermediate between our Big Ben recessional moraines and our Lake Coleridge samples. Using the data presented by Shulmeister et al. (2010), we have recalculated ages for their 


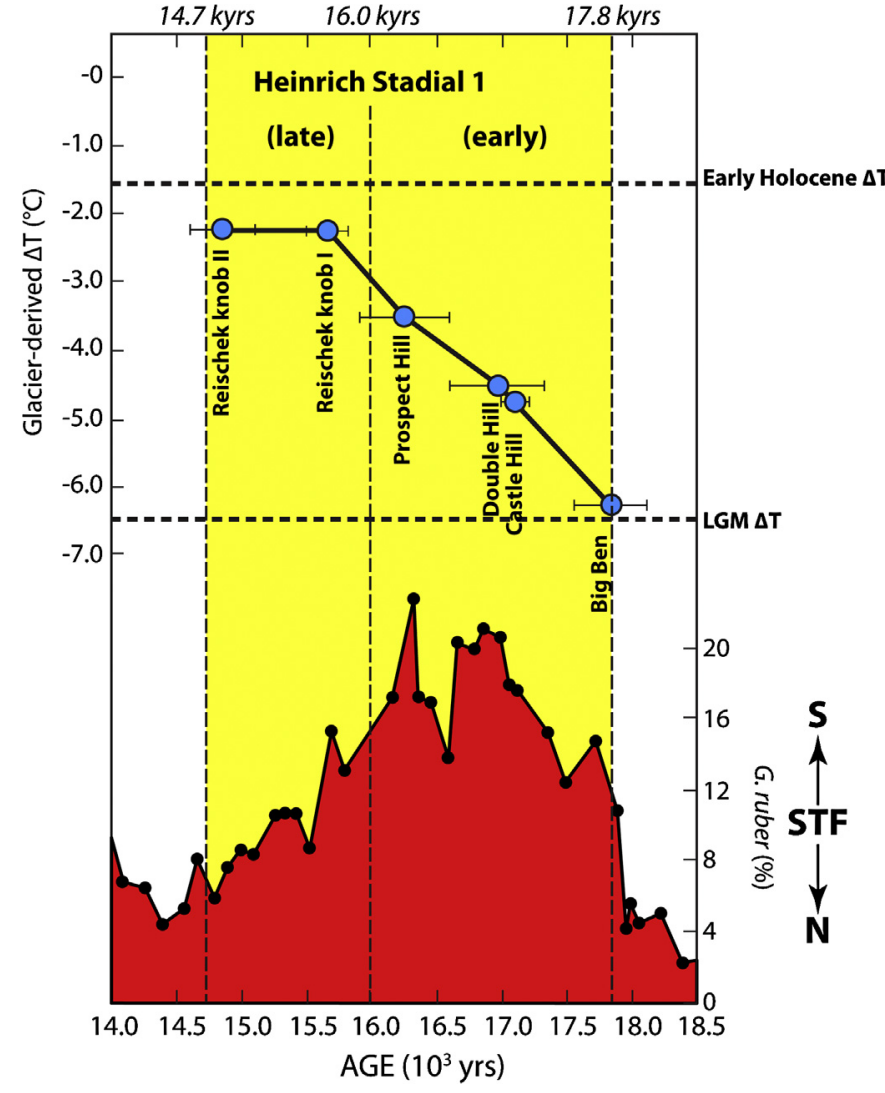

Fig. 7. Comparison between Rakaia glacier-inferred $\Delta T$ and the STF. Top panel Glacier-inferred palaeotemperature reconstruction, based on the Rakaia valley glacier record (this study). Horizontal dashed lines depict LGM and early Holocene $\Delta T$ values for the Southern Alps [LGM $\Delta T$ is based on Rowan et al., 2013; Golledge et al., 2012; and Putnam et al., 2013; early Holocene values were determined by Putnam et al., 2012 and Kaplan et al., 2013]. Bottom panel: Percent G. ruber in core MD03-2611, recording influxes of tropical water south of Australia and hence the latitudinal position of the STF (De Deckker et al., 2012). Yellow band represents full duration of Heinrich Stadial 1, whereas vertical dashed lines demarcate its early and late phases. (For interpretation of the references to color in this figure legend, the reader is referred to the web version of this article.)

${ }^{10} \mathrm{Be}$ samples on the same basis as the ages that we present in this paper (Appendix A, Tables S3-S5). In order to account for the relatively large error terms in the Shulmeister et al. (2010) ${ }^{10} \mathrm{Be}$ measurements, we report arithmetic mean ages $\pm 2 \sigma$, using the 'Lm' scaling scheme, for different grouping of moraines as shown in Table S5. Although the number of samples from each of their moraine areas is too few for the robust identification of outliers, three of their samples are sufficiently dissimilar from adjacent samples that we suspect that they are outliers (Table S5). A mean age calculated for the full set of their Bayfield, Acheron, and Coleridge samples, with those three outlier samples excluded, is $17,800 \pm 2200$ yrs. Thus, the ${ }^{10}$ Be measurements from the Shulmeister et al. (2010) reconnaissance dating study, despite their relatively low analytical precision and considerable scatter, are generally compatible with our findings. However, our results, from sites in the middle to upper reaches of the Rakaia catchment show that the Shulmeister et al. (2010) interpretation of the glacier having survived in the Rakaia valley at close to LGM positions until at least $\sim 15,000$ yrs ago is incorrect.

The recession history for the Rakaia glacier determined in our study is similar to that described for the Lake Ohau and Lake Pukaki glaciers of the Southern Alps, and for glaciers in southern South America. At Lake Ohau, deglaciation commenced $\sim 17,700$ yrs ago and by $\sim 17,380$ yrs ago, the Ohau glacier had diminished to $\sim 40 \%$ of its LGM size. By $\sim 13,000$ yrs ago, ice had receded well into the mountains of the Ohau catchment. At Lake Pukaki, deglaciation commenced at $\sim 18,350$ yrs ago (Putnam et al., 2010a, 2010b). By $\sim 16,400$ yrs ago, the glacier had receded to a position that was more than half the distance from LGM to present-day glacier limits (Moar, 1980; Putnam et al., 2010a). Furthermore, the ice recession from the Rakaia LGM moraines that began $\sim 17,840$ yrs ago coincided with the onset of sustained climate amelioration, as recognized in a variety of biological and isotopic proxy records across the New Zealand region (Alloway et al., 2007; Barrell et al., 2013; Vandergoes et al., 2013).

The final advances of Patagonian Ice Sheet outlet glaciers into the LGM moraine belt of the Chilean Lake District (39-43 $\mathrm{S}$ ) culminated $\sim 18,000$ yrs ago (Denton et al., 1999b). Ice recession began shortly thereafter, with retreat to within $\sim 10 \mathrm{~km}$ of present-day glacier limits before $\sim 14,600$ yrs ago (Heusser, 1990; Denton et al., 1999a, 1999b). Likewise, at $\sim 50^{\circ} \mathrm{S}$ at Lago Argentino, an eastwarddraining outlet glacier of the Patagonian Ice Sheet had receded to a position up-valley of its late-glacial moraine belt by 16,400 yrs ago

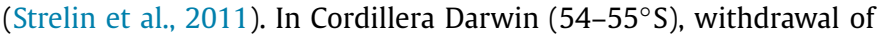
glaciers from LGM to near-present-day limits had taken place by $\sim 16,800$ yrs ago (Hall et al., 2013).

Warming inferred from our glacier-derived climate reconstruction is similar to that indicated by sea-surface temperature (SST) records developed from marine cores located in the vicinity of the STF. For example, Calvo et al. (2007) and De Deckker et al. (2012) determined that SSTs south of Australia warmed by $4-5^{\circ} \mathrm{C}$ between $\sim 17,800$ and $\sim 15,000$ yrs ago, with as much as $3{ }^{\circ} \mathrm{C}$ of that warming between $\sim 17,800$ and $\sim 17,000$ yrs ago. De Deckker et al. (2012) interpreted this SST increase south of Australia, together with coeval incursions of tropical foraminifera species, to reflect a southward shift of the austral westerlies and the STF at the onset of the last glacial termination (Fig. 7). Southward migration of the austral westerly wind belt (e.g., Sikes et al., 2013) would have diminished the incidence of cool southwesterly air flowing over Southern Alps glaciers (Tyson et al., 1997), while an associated southward shift of the STF would have brought warmer surface water to that part of the Tasman Sea west of the Southern Alps, as seen for example in the SST reconstructions of Barrows et al. (2007), Petherick et al. (2013), and Sikes et al. (2013). In addition, warming of the Western Pacific Warm Pool 18,000-15,000 yrs ago (e.g., Stott et al., 2007) leaves open the possibility for a tropical role in Southern Alps deglaciation. An expanded Western Pacific Warm Pool, perhaps due to southwarddisplaced and/or weaker trade winds associated with a southwarddisplaced intertropical convergence zone (Kanner et al., 2012; Ceppi et al., 2013), could have strengthened and warmed the East Australian Current, increasing downstream SSTs in the Tasman Sea as well as shifting the Tasman Front and STF southward [e.g., similar to the mechanism described in Putnam et al., 2012]. Each of these complementary atmospheric and oceanic processes would have stimulated snowline rise and glacier recession in the Southern Alps.

An abrupt sea-surface warming that began 18,000 yrs ago has been identified from cores at $41^{\circ} \mathrm{S}$ in the southeast Pacific (Lamy et al., 2004, 2007; Strelin et al., 2011) and in the South Atlantic (Barker et al., 2009) and has been attributed to a southward migration of the STF. Rapid, large-scale recession of Patagonian glaciers and Southern Alps glaciers between $\sim 18,000$ and $\sim 16,000$ yrs ago is considered to reflect widespread atmospheric warming in the southern mid-latitudes, and is consistent with a coupled southward shift of the austral westerlies, STF, and the Subantarctic Front (SAF) (Strelin et al., 2011; Hall et al., 2013). Tropical warming may have exacerbated this mid-latitude warming.

Gradual Antarctic warming and $\mathrm{CO}_{2}$ rise also commenced $\sim$ 17,800 yrs ago (Monnin et al., 2001; Lemieux-Dudon et al., 2010; Parrenin et al., 2013). We consider that Antarctic warming and 
atmospheric $\mathrm{CO}_{2}$ increase were mainly a consequence of progressive reduction of Southern Ocean sea-ice cover (Bianchi and Gersonde, 2004; Divine et al., 2010) and breakdown of stratification (Burke and Robinson, 2012), both of which are partly attributable to a southward shift of the austral westerlies (Toggweiler et al., 2006; Anderson et al., 2009). Progressive destratification of the Southern Ocean (Anderson et al., 2009; Burke and Robinson, 2012), in conjunction with the warming effects of increasing atmospheric $\mathrm{CO}_{2}$ (Lorius et al., 1990; Monnin et al., 2001; Parrenin et al., 2013), would have increased the temperature of the Southern Ocean as a whole, augmenting mid-latitude warming arising from southward migration of the STF and SAF.

However, Heinrich Stadial 1 (HS1) sea-surface cooling and stratification in the North Atlantic Ocean commenced at $\sim 17,900$ yrs ago (Bard et al., 2000; Cheng et al., 2009), at the same time as general warming in the Southern Hemisphere middle-to-high latitudes and the onset of extensive ice recession from the Big Ben LGM moraines of the Rakaia valley. Southern Hemispheric warming coeval with North Atlantic cooling is consistent with the operation of a 'bipolar seesaw' mechanism for transmitting climate anomalies between the polar hemispheres. However, still unclear is whether this seesaw operated through the ocean interior (Crowley, 1992; Broecker, 1998; Meckler et al., 2013), the atmosphere (Toggweiler et al., 2006; Anderson et al., 2009; Toggweiler and Lea, 2010), or through an interlocked switch in both oceanic and atmospheric circulation (Barker et al., 2009, 2011; Denton et al., 2010).

Because a southward shift of the wind-driven STF occurred coevally with the beginning of HS1 (De Deckker et al., 2012), and because Southern Alps glacier activity appears intrinsically linked to the position of the austral westerlies and/or the STF (Harrington, 1952; Putnam et al., 2010a, 2013), we consider it most likely that a general southward shift of the austral westerlies drove southward contraction of Southern Ocean fronts and in turn initiated the last glacial termination in southern middle latitudes during HS1 (Denton et al., 2010; Hall et al., 2013). Therefore, we favor an atmospheric mechanism for transmitting climate anomalies between the hemispheres (Anderson et al., 2009; Denton et al., 2010; Lee et al., 2011; Ceppi et al., 2013), that produced sustained warming and glacier recession at Southern Hemisphere middle latitudes during HS1. As the austral westerlies and STF shifted equatorward at the onset of the Antarctic Cold Reversal (Putnam et al., 2010a), the new background condition of a warmer, destratified Southern Ocean and elevated atmospheric carbon dioxide levels may have prevented Southern Hemisphere middle-to-high latitude climate from reverting back into ice-age conditions.

\section{Conclusions}

Our ${ }^{10} \mathrm{Be}$ chronology of landforms in the Rakaia valley, Southern Alps of New Zealand, indicates that extensive deglaciation in this valley occurred between $\sim 17,840$ and $\sim 15,660$ yrs ago, coinciding with HS1 in the North Atlantic region. The glacier recession is attributed primarily to atmospheric warming, which we estimate to have been $4.0^{\circ} \mathrm{C}$ based on glaciological modeling. This represents $86 \%$ (from -6.25 to $-2.25^{\circ} \mathrm{C}$ ) of the total temperature rise in the Southern Alps between the end of the LGM and the beginning of the Holocene. Overall, our results are favorable to the hypothesis that northern cooling associated with HS1 induced a southward shift of the earth's thermal equator, the austral westerlies, and southern oceanic fronts. Consequent destratification of the Southern Ocean, reduction of sea-ice cover, and elevation of atmospheric $\mathrm{CO}_{2}$ levels had, by the end of HS1, securely locked the Southern Hemisphere into an interglacial mode. Such a mechanism affords an explanation for the last glacial termination in southern middle latitudes, as recorded in the deglaciation chronology of the Rakaia valley.

\section{Acknowledgements}

We are grateful to the Gary $C$. Comer Science and Education Foundation (CSEF), the Quesada Family Foundation, the National Oceanographic and Atmospheric Administration (NOAA) and the National Science Foundation (NSF grants EAR-1102782, EAR-0345835, and EAR-0745781) for financial support. A.E. Putnam was supported by CSEF, NOAA, and a Lamont Doherty Earth Observatory (LDEO) postdoctoral fellowship while conducting this research. T.N.B. Koffman was supported by an NSF graduate research fellowship (grant no. DGE-1144205) while conducting this research. GNS Science's Direct Crown Funded Programme 'Global Change through Time' supported D.J.A. Barrell. We benefited from insightful discussions with R.F. Anderson, U.S. Ninnemann, W.S. Broecker, B.L. Hall, G. Haug, D.M. Sigman, K.A. Allen, R.B. Alley, M.R. Kaplan, and A.M. Doughty. R. Braucher and two anonymous reviewers provided constructive criticism that improved the paper. We are grateful to J. Shrimpton (Glenthorne Station), A. and T. Hutchinson (Double Hill Station), P. Wareing (Mt Arrowsmith), B. and M. May (Big Ben Station), P. and A. Todhunter (Lake Heron Station), the Department of Conservation - Te Papa Atawhai, and Te Rünanga o Ngäi Tahu for permitting us access to their lands. We thank Tony and Kura Ritchie of Lake Ruataniwha Holiday Park for excellent accommodation and gracious hospitality. This paper is LDEO contribution no. 7728 .

\section{Appendix A. Supplementary material}

Supplementary material related to this article can be found online at http://dx.doi.org/10.1016/j.epsl.2013.09.005.

\section{References}

Alloway, B.V., Lowe, D.J., Barrell, D.J.A., Newnham, R.M., Almond, P.C., Augustinus, P.C., Bertler, N.A.N., Carter, L., Litchfield, N.J., McGlone, M.S., Shulmeister, J., Vandergoes, M.J., Williams, P.W., NZ-INTIMATE members, 2007. Towards a climate event stratigraphy for New Zealand over the past 30000 years (NZ-INTIMATE project). J. Quat. Sci. 22, 9-35.

Anderson, B., 2005. Interactive comment on "Synoptic climate change as a driver of late Quaternary glaciations in the mid-latitudes of the Southern Hemisphere" by H. Rother and J. Shulmeister. Clim. Past Discuss. 1, S161-S167.

Anderson, B., Mackintosh, A., 2006. Temperature change is the major driver of lateglacial and Holocene glacier fluctuations in New Zealand. Geology 34, 121-124.

Anderson, B., Mackintosh, A., 2012. Controls on mass balance sensitivity of maritime glaciers in the Southern Alps, New Zealand: The role of debris cover. J. Geophys. Res. 117. F01003.

Anderson, B., Lawson, W., Owens, I., Goodsell, B., 2006. Past and future mass balance of 'Ka Roimata o Hine Hukatere' Franz Josef Glacier, New Zealand. J. Glaciol. 52, 597-607.

Anderson, R.F., Ali, S., Bradtmiller, L.I., Nielsen, S.H.H., Fleisher, M.Q., Anderson, B.E., Burckle, L.H., 2009. Wind-driven upwelling in the southern ocean and the deglacial rise in atmospheric $\mathrm{CO}_{2}$. Science 323, 1443-1448.

Anderson, B., Mackintosh, A., Stumm, D., George, L., Kerr, T., Winter-Billington, A. Fitzsimons, S., 2010. Climate sensitivity of a high-precipitation glacier in New Zealand. J. Glaciol. 56, 114-128.

Bard, E., Rostek, F., Turon, J.L., Gendreau, S., 2000. Hydrological impact of Heinrich events in the subtropical northeast Atlantic. Science 289, 1321-1324.

Barker, S., Diz, P., Vautravers, M.J., Pike, J., Knorr, G., Hall, I.R., Broecker, W.S., 2009 Interhemispheric Atlantic seesaw response during the last deglaciation. Nature 457, 1097-1102.

Barker, S., Knorr, G., Edwards, R.L., Parrenin, F., Putnam, A.E., Skinner, L.C., Wolff, E., Ziegler, M., 2011. 800,000 years of abrupt climate variability. Science 334 347-351.

Barrell, D.J.A., 2011. Quaternary glaciers of New Zealand. In: Ehlers, J., Gibbard, P.L., Hughes, P.D. (Eds.), Quaternary Glaciations-Extent and Chronology, Part IV. A Closer Look. Elsevier, Amsterdam, pp. 1047-1064.

Barrell, D.J.A., Andersen, B.G., Denton, G.H., 2011. Glacial Geomorphology of the Central South Island, New Zealand. GNS Sci. Monogr., vol. 27. Lower Hutt, New Zealand, Map and $71 \mathrm{pp}$.

Barrell, D.J.A., Almond, P.C., Vandergoes, M.J., Lowe, D.J., Newnham, R.M., NZINTIMATE members, 2013. A composite pollen-based stratotype for interregional evaluation of climatic events in New Zealand over the past 30,000 years (NZ-INTIMATE project). Quat. Sci. Rev. 74, 4-20. 
Barrows, T.T., Juggins, S., De Deckker, P., Calvo, E., Pelejero, C., 2007. Long-term sea surface temperature and climate change in the Australian-New Zealand region. Paleoceanography 22. PA22215.

Bianchi, C., Gersonde, R., 2004. Climate evolution at the last deglaciation: the role of the Southern Ocean. Earth Planet. Sci. Lett. 228, 407-424.

Bostock, H.C., Barrows, T.T., Carter, L., Chase, Z., Cortese, G., Dunbar, G.B., Ellwood, M. Hayward, B., Howard, W., Neil, H.L., Noble, T.L., Mackintosh, A., Moss, P.T., Moy, A.D., White, D., Williams, M.J.M., Armand, L.K., 2013. A review of the AustralianNew Zealand sector of the Southern Ocean over the last 30 ka (Aus-INTIMATE project). Quat. Sci. Rev. 74, 35-57.

Broecker, W.S., 1998. Paleocean circulation during the last deglaciation: A bipolar seesaw? Paleoceanography 13, 119-121.

Broecker, W.S., Denton, G.H., 1989. The role of ocean-atmosphere reorganizations in glacial cycles. Geochim. Cosmochim. Acta 53, 2465-2501.

Broecker, W.S., van Donk, J., 1970. Insolation changes, ice volume, and the ${ }^{18} \mathrm{O}$ record in deep-sea cores. Rev. Geophys. 8, 169-198.

Burke, A., Robinson, L.F., 2012. The Southern Ocean's role in carbon exchange during the last deglaciation. Science 335, 557-561.

Burrows, C.J., Russell, J.B., 1975. Moraines of the upper Rakaia Valley. J. R. Soc. N.Z. 5 463-477.

Calvo, E., Pelejero, C., De Deckker, P., Logan, G.A., 2007. Antarctic deglacial pattern in a $30 \mathrm{kyr}$ record of sea surface temperature offshore South Australia. Geophys. Res. Lett. 34. L13707.

Carter, L., Garlick, R.D., Sutton, P., Chiswell, S., Oien, N.A., Stanton, B.R., 1998. Ocean Circulation in New Zealand. NIWA Chart Miscellaneous Ser., vol. 76. NIWA Wellington.

Ceppi, P., Hwang, Y.-T., Liu, X., Frierson, D.M.W., Hartmann, D.L., 2013. The relationship between the ITCZ and Southern Hemispheric eddy-driven jet. J. Geophys. Res. 118, 5136-5146.

Cheng, H., Edwards, R.L., Broecker, W.S., Denton, G.H., Kong, K., Wanf, Y., Zang, R. Wang, Z., 2009. Ice age terminations. Science 326, 248-252.

Clark, P.U., Shakun, J.D., Baker, P.A., Bartlein, P.J., Brewer, S., Brook, E., Carlson, A.E., Cheng, H., Kaufman, D.S., Liu, Z., Marchitto, T.M., Mix, A.C., Morrill, C., OttoBliesner, B.L., Pahnke, K., Russell, J.M., Whitlock, C., Adkins, J.F., Blois, J.L., Clark, J., Colman, S.M., Curry, B.B., Flower, B.P., He, F., Johnson, T.C., Lynch-Steiglitz, J., Markgraf, V., McManus, J., Mitrovica, J.X., Moreno, P.I., Williams, J.W., 2012. Global climate evolution during the last deglaciation. Proc. Natl. Acad. Sci. USA 109, E1134-E1142, http://dx.doi.org/10.1073/pnas.1116619109.

Cox, S.C., Barrell, D.J.A., 2007. Geology of the Aoraki area. GNS Science, Lower Hut, New Zealand. Institute of Geological and Nuclear Sciences 1:250,000 Geological Map 15, 1 sheet and 71 pp.

Crowley, T.J., 1992. North Atlantic deep water cools the Southern Hemisphere. Paleoceanography 7, 489-497.

De Deckker, P., Moros, M., Perner, K., Jansen, E., 2012. Influence of the tropics and southern westerlies on glacial interhemispheric asymmetry. Nat. Geosci. 5, 266-269.

Denton, G.H., Heusser, C.J., Lowell, T.V., Moreno, P.I., Andersen, B.G., Heusser, L.E. Schluchter, C., Marchant, D.R., 1999a. Interhemispheric linkage of paleoclimate during the last glaciation. Geogr. Ann. 81A, 107-153.

Denton, G.H., Lowell, T.V., Heusser, C.J., Schlüchter, C., Andersen, B.G., Heusser, L.E. Moreno, P.I., Marchant, D.R., 1999b. Geomorphology, stratigraphy, and radiocarbon chronology of Llanquihue drift in the area of the southern Lake District, Seno Reloncaví, and Isla Grande de Chiloé, Chile. Geogr. Ann. 81A, 167-229.

Denton, G.H., Anderson, R.F., Toggweiler, J.R., Edwards, R.L., Schaefer, J.M., Putnam, A.E., 2010. The last glacial termination. Science 328, 1652-1656.

Divine, D.V., Koç, N., Isaksson, E., Nielsen, S., Crosta, X., Godtliebsen, F., 2010. Holocene Antarctic climate variability from ice and marine sediment cores: Insights on ocean-atmosphere interaction. Quat. Sci. Rev. 29, 303-312.

Doughty, A.M., Anderson, B.M., Mackintosh, A.N., Kaplan, M.R., Vandergoes, M.J., Barrell, D.J.A., Denton, G.H., Schaefer, J.M., Chinn, T.J.H., Putnam, A.E., 2012. Evaluation of Lateglacial temperatures in the Southern Alps of New Zealand based on glacier modelling at Irishman Stream, Ben Ohau Range. Quat. Sci. Rev. 74, $160-169$.

Golledge, N.R., Mackintosh, A.N., Anderson, B.M., Buckley, K.M., Doughty, A.M., Barrell, D.J.A., Denton, G.H., Vandergoes, M.J., Andersen, B.G., Schaefer, J.M., 2012 Last Glacial Maximum climate in New Zealand inferred from a modelled Southern Alps icefield. Quat. Sci. Rev. 46, 30-45.

Hall, B.L., Porter, C.T., Denton, G.H., Lowell, T.V., Bromley, G.R.M., 2013. Extensive recession of Cordillera Darwin glaciers in southernmost South America during Heinrich Stadial 1. Quat. Sci. Rev. 62, 49-55.

Harrington, H.J., 1952. Glacier wasting and retreat in the Southern Alps of New Zealand. J. Glaciol. 2, 140-144.

Heusser, C.J., 1990. Chilotan piedmont glacier in the southern Andes during the last glacial maximum. Rev. Geol. Chile 17, 3-18.

Kanner, L.C., Burns, S.J., Cheng, H., Edwards, R.L., 2012. High-latitude forcing of the South American Summer Monsoon during the last glacial. Science 335, 570-573.

Kaplan, M.R., Schaefer, J.M., Denton, G.H., Barrell, D.J.A., Chinn, T.J.H., Putnam, A.F. Andersen, B.G., Finkel, R.C., Schwartz, R., Doughty, A.M., 2010. Glacier retreat in New Zealand during the Younger Dryas stadial. Nature 467, 194-197.

Kaplan, M.R., Strelin, J.A., Schaefer, J.M., Denton, G.H., Finkel, R.C., Schwartz, R., Putnam, A.E., Vandergoes, M.J., Goehring, B.M., Travis, S.G., 2011. In-situ cosmogenic
${ }^{10}$ Be production rate at Lago Argentino, Patagonia: Implications for late-glacial climate chronology. Earth Planet. Sci. Lett. 309, 21-32.

Kaplan, M.R., Schaefer, J.M., Denton, G.H., Doughty, A.M., Barrell, D.J.A., Chinn, T.J.H., Putnam, A.E., Andersen, B.G., Mackintosh, A., Finkel, R.C., Schwartz, R., Anderson, B., 2013. The anatomy of long-term warming since $15 \mathrm{kyr}$ ago in New Zealand based on net glacier snowline rise. Geology 41, 887-890.

Lal, D., 1991. Cosmic-ray labeling of erosion surfaces: in situ nuclide production rates and erosion models. Earth Planet. Sci. Lett. 104, 424-439.

Lamy, F., Kaiser, J., Ninnemann, U., Hebbeln, D., Arz, H.W., Stoner, J., 2004. Antarctic timing of surface water changes off Chile and Patagonian ice sheet response. Science 304, 1959-1962.

Lamy, F., Kaiser, J., Arz, H.W., Hebbeln, D., Ninnemann, U., Timm, O., Timmermann, A., Toggweiler, J.R., 2007. Modulation of the bipolar seesaw in the southeast Pacific during Termination 1. Earth Planet. Sci. Lett. 259, 400-413.

Lee, S.-Y., Chiang, J.C.H., Matsumoto, K., Tokos, K.S., 2011. Southern Ocean wind response to North Atlantic cooling and the rise in atmospheric $\mathrm{CO}_{2}$ : Modeling perspective and paleoceanographic implications. Paleoceanography 26. PA1214.

Lemieux-Dudon, B., Blayo, E., Petit, J.R., Waelbroeck, C., Svensson, A., Ritz, C., Barnola, J.-M., Narcisa, B.M., Parrenin, F., 2010. Consistent dating for Antarctic and Greenland ice cores. Quat. Sci. Rev. 29, 8-20.

Lifton, N., Smart, B., Shea, M., 2008. Scaling time-integrated in situ cosmogenic nuclide production rates using a continuous geomagnetic model. Earth Planet. Sci. Lett. 268, 190-201.

Lorius, C., Jouzel, J., Raynaud, D., Hansen, J., Letreut, H., 1990. The ice-core recordClimate sensitivity and future greenhouse warming. Nature 347, 139-145.

McKinnon, K.A., Mackintosh, A.N., Anderson, B.M., Barrell, D.J.A., 2012. The influence of sub-glacial bed evolution on ice extent: a model-based evaluation of the Last Glacial Maximum Pukaki glacier, New Zealand. Quat. Sci. Rev. 57, 46-57.

Meckler, A.N., Sigman, D.M., Gibson, K.A., François, R., Martínez-Garcia, A., Jaccard, S.L., Röhl, U., Peterson, L.C., Tiedemann, R., Haug, G.H., 2013. Deglacial pulses of deep-ocean silicate into the subtropical North Atlantic Ocean. Nature 495, 495-499.

Moar, N.T., 1980. Late Otiran and early Aranuian grassland in central South Isand. N.Z. J. Ecol. 3, 4-12.

Monnin, E., Indermühle, A., Dällenbach, A., Flückiger, J., Stauffer, B., Stocker, T.F., Raynaud, D., Barnola, J.-M., 2001. Atmospheric $\mathrm{CO}_{2}$ concentrations over the Last Glacial Termination. Science 291, 112-114.

Oerlemans, J., 1997. Climate sensitivity of Franz Josef Glacier, New Zealand, as revealed by numerical modelling. Arct. Alp. Res. 29, 233-239.

Parrenin, F., Masson-Delmotte, V., Köhler, P., Raynaud, D., Paillard, D., Schwander, J., Barbante, C., Landais, A., Wegner, A., Jouzel, J., 2013. Synchronous change of atmospheric $\mathrm{CO}_{2}$ and Antarctic temperature during the last deglacial warming. Science 339, 1060-1063.

Petherick, L., Bostock, H.C., Cohen, A.S., Fitzsimmons, K., Tibby, J., Fletcher, M.-S., Moss, P., Reeves, J., Mooney, S., Barrows, T., Kemp, J., Jansen, J., Nanson, G., Dosseto, A., 2013. Climatic records over the past $30 \mathrm{ka}$ from temperate AustraliaA synthesis from the Oz-INTIMATE workgroup. Quat. Sci. Rev. 74, 58-77.

Plummer, M.A., Phillips, F.M., 2003. A 2-D numerical model of snow/ice energy balance and ice flow for paleoclimatic interpretation of glacial geomorphic features. Quat. Sci. Rev. 2003, 1389-1406.

Purdie, H., Mackintosh, A., Lawson, W., Anderson, B., Morgenstern, U., Chinn, T., Mayewski, P., 2011. Interannual variability in net accumulation on Tasman Glacier and its relationship with climate. Glob. Planet. Change 77, 142-152, http://dx.doi.org/10.1016/j.gloplacha.2011.04.004.

Putnam, A.E., Denton, G.H., Schaefer, J.M., Barrell, D.J.A., Andersen, B.G., Finkel, R., Schwartz, R., Doughty, A.M., Kaplan, M., Schlüchter, C., 2010a. Glacier advance in southern middle latitudes during the Antarctic Cold Reversal. Nat. Geosci. 3, 700-704.

Putnam, A.E., Schaefer, J.M., Barrell, D.J.A., Vandergoes, M., Denton, G.H., Kaplan, M.R., Schwartz, R., Finkel, R.C., Goehring, B.M., Kelley, S.E., 2010b. In situ cosmogenic ${ }^{10}$ Be production-rate calibration from the Southern Alps, New Zealand. Quat. Geochronol. 5, 392-409.

Putnam, A.E., Schaefer, J.M., Denton, G.H., Barrell, D.J.A., Finkel, R.C., Andersen, B.G., Schwartz, R., Chinn, T.J.H., Doughty, A.M., 2012. Regional climate control of glaciers in New Zealand and Europe during the pre-industrial Holocene. Nat. Geosci. 5, 627-630.

Putnam, A.E., Schaefer, J.M., Denton, G.H., Barrell, D.J.A., Birkel, S.D., Andersen, B.G., Kaplan, M.R., Finkel, R.C., Schwartz, R., Doughty, A.M., 2013. The Last Glacial Maximum at $44^{\circ} \mathrm{S}$ documented by a ${ }^{10} \mathrm{Be}$ moraine chronology at Lake Ohau, Southern Alps of New Zealand. Quat. Sci. Rev. 62, 114-141.

Rowan, A.V., Plummer, M.A., Brocklehurst, S.H., Jones, M.A., Schultz, D.M., 2013. Drainage capture and discharge variations driven by glaciation in the Southern Alps, New Zealand. Geology 41, 199-202.

Schaefer, J.M., Denton, G.H., Barrell, D.J.A., Ivy-Ochs, S., Kubik, P.W., Andersen, B.G., Phillips, F.M., Lowell, T.V., Schluchter, C., 2006. Near-synchronous interhemispheric termination of the last glacial maximum in mid-latitudes. Science 312, 1510-1513.

Schaefer, J.M., Denton, G.H., Kaplan, M., Putnam, A., Finkel, R.C., Barrell, D.J.A., Andersen, B.G., Schwartz, R., Mackintosh, A., Chinn, T., Schlüchter, C., 2009. Highfrequency Holocene glacier fluctuations in New Zealand differ from the northern signature. Science 324, 622-625. 
Shakun, J.D., Clark, P.U., Feng, H., Marcott, S.A., Mix, A.C., Liu, Z., Otto-Bliesner, B., Schmittner, A., Bard, E., 2012. Global warming preceded by increasing carbon dioxide concentrations during the last deglaciation. Nature 484, 49-54.

Shulmeister, J., Fink, D., Hyatt, O.M., Thackray, G.D., Rother, H., 2010. Cosmogenic ${ }^{10} \mathrm{Be}$ and ${ }^{26} \mathrm{Al}$ exposure ages of moraines in the Rakaia Valley, New Zealand and the nature of the last termination in New Zealand glacial systems. Earth Planet. Sci. Lett. 297, 558-566, http://dx.doi.org/10.1016/j.epsl.2010.1007.1007.

Sikes, E.L., Howard, W.R., Samson, C.R., Mahan, T.S., Robertson, L.G., Volkman, J.K., 2009. Southern Ocean seasonal temperature and Subtropical Front movement on the South Tasman Rise in the late Quaternary. Paleoceanography 24. PA2201.

Sikes, E.L., Medeiros, P.M., Augustinus, P., Wilmshurst, J.M., 2013. Seasonal variations in aridity and temperature characterize changing climate during the last deglaciation in New Zealand. Quat. Sci. Rev. 74, 245-256.

Soons, J.M., 1963. The glacial sequence in part of the Rakaia Valley, Canterbury, New Zealand. N.Z. J. Geol. Geophys. 6, 735-756

Soons, J.M., Gullentops, F.W., 1973. Glacial advances in the Rakaia Valley, New Zealand. N.Z. J. Geol. Geophys. 16, 425-438.

Stone, J.O., 2000. Air pressure and cosmogenic isotope production. J. Geophys. Res. 105, 23753-23759.

Stott, L., Timmermann, A., Thunell, R., 2007. Southern hemisphere and deep-sea warming led deglacial atmospheric $\mathrm{CO}_{2}$ rise and tropical warming. Science 318, 435-438.
Strelin, J.A., Denton, G.H., Vandergoes, M.J., Ninnemann, U.S., Putnam, A.E., 2011 Radiocarbon chronology of the late-glacial Puerto Bandera moraines, Southern Patagonian Icefield, Argentina. Quat. Sci. Rev. 30, 2551-2569.

Suggate, R.P., 1963. The fan surfaces of the central Canterbury Plain. N.Z. J. Geol. Geophys. 6, 281-287.

Suggate, R.P., 1965. Late Pleistocene geology of the northern part of the South Island, New Zealand. N. Z. Geol. Surv. Bull. 77, 1-99.

Suggate, R.P., 1990. Late Pliocene and Quaternary glaciations of New Zealand. Quat Sci. Rev. 9, 175-197.

Suggate, R.P., Almond, P.C., 2005. The Last Glacial Maximum (LGM) in western South Island, New Zealand: implication for the global LGM and MIS 2. Quat. Sci. Rev. 24, 1923-1940.

Toggweiler, J.R., Lea, D.W., 2010. Temperature differences between the hemispheres and ice age climate variability. Paleoceanography 25. PA2212.

Toggweiler, J.R., Russell, J.L., Carson, S.R., 2006. Midlatitude westerlies, atmospheric $\mathrm{CO}_{2}$, and climate change during the ice ages. Paleoceanography 21. PA2005.

Tyson, P.D., Sturman, A.P., Fitzharris, B.B., Mason, S.J., Owens, I.F., 1997. Circulation changes and teleconnections between glacial advances on the west coast of New Zealand and extended spells of drought years in South Africa. Int. J. Climatol. 17, 1499-1512.

Vandergoes, M.J., Newnham, R.M., Denton, G.H., Blaauw, M., Barrell, D.J.A., 2013 The anatomy of Last Glacial Maximum climate variations in south Westland New Zealand, derived from pollen records. Quat. Sci. Rev. 74, 215-229. 